
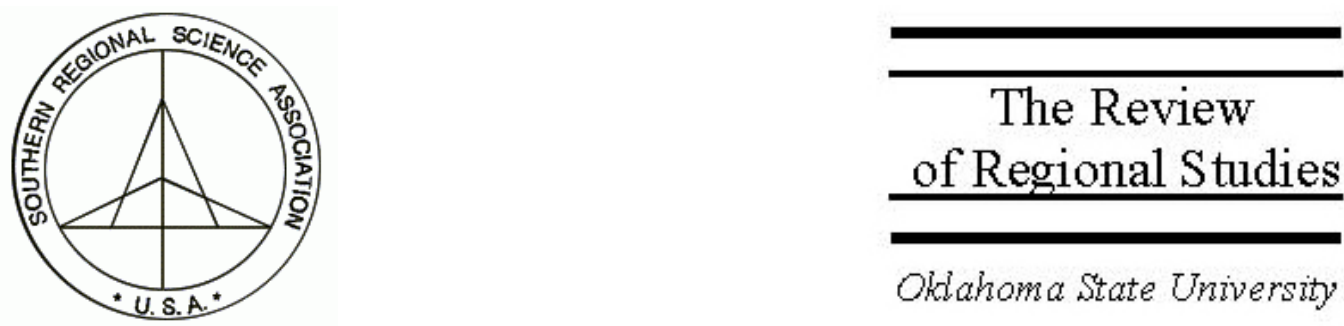

\title{
Spatial Modeling of the Migration of Older People with a Focus on Amenities
}

\author{
Tomas Jensen \\ Department of Agricultural and Applied Economics, University of Wisconsin - Madison, \\ Madison, WI 53706 \\ Steven Deller \\ Department of Agricultural and Applied Economics, 521 Taylor Hall - 427 Lorch St, \\ University of Wisconsin - Madison/Extension, Madison, WI 53706, \\ e-mail:deller@aae.wisc.edu
}

\begin{abstract}
Using U.S. county-level migration data from the 2000 Census, we examine patterns of migration of older people. This study makes three contributions to the literature. First we focus attention on differences in migration patterns of older people by separately modeling four age classifications. Second, using Geographically Weighted Regression (GWR), we look for and find significant spatial variation in the determinants of migration of older people. Third, because many older migrants relocate purely for quality of life, we examine the role of amenities, both natural and built, in explaining migration patterns.
\end{abstract}

Keywords: Amenities; Elderly Migration; Rural Development

JEL classification: Q56; O15; R15

An earlier version of this paper was presented at the 53rd Annual North American Meetings of the Regional Science Association International, Toronto, Canada, November 16-18th, 2006. Support for this research was provided by the Wisconsin Agricultural Experiment Station, University of Wisconsin - Madison, and the USDA Forest Service Southern Experiment Station, Athens, GA. We appreciate the helpful comments of Paul Voss and two reviewers of the Review. All errors are the responsibility of the authors. 


\section{INTRODUCTION}

The aging of the population and the increasing number of retirees will be the most important demographic event of the twenty-first century. Demographers, sociologists, geographers, and economists are all among the disciplinary professions interested in examining the migration and location decisions of older people. Migration research has extended well beyond its beginnings with E.G. Ravenstein's papers of the 1880s and the narrow focus of movement of people based solely on employment and income decisions. The inclusion of policy- and place-based characteristics has been examined not only to improve our academic understanding of migration but also to lay the foundation for potential policy tools that can be implemented to attract migrants. Numerous studies, such as Haas and Serow (1993), Choi (1996), and Clark and Hunter (1992) to name a few, have examined the importance of location-specific amenities and their effect on the migration decisions of older people.

The attraction of older migrants has been deemed by some as a new engine of economic growth for some rural areas (Haas 1990; Deller 1995; Isserman 2001). Many studies have shown that retired migrants create jobs when they move to an area (Stallmann and Siegel 1995; Green et al. 1996; Stallmann, Deller, and Shields 1999). But if policies are to be crafted to help influence these migration flows, it is vital to gain as much insight into what drives them as possible (Stillwell and Congdon 1990). The goal of this research is to more accurately model the movements of the older population with a focus on the role of amenities, broadly defined.

To accomplish this goal, we use two statistical approaches - aspatial regression along with Geographically Weighted Regression (GWR). The aspatial dimensions are the relationships between migration and presence or absence of amenities. We then move away from a more global model to more specifically identify the local conditions that affect migration decisions. Geographically Weighted Regression (GWR) is a form of spatial modeling developed by Fotheringham, Brunsdon, and Charlton (2002) that allows us to calculate and map local parameter estimates to emphasize differences across space.

A second important element that we explore is the variation in migration patterns across age groups. As noted by Stallmann, Deller, and Shields (1999), there is significant variation in what we are broadly calling "older migrants." For example, what drives the migration decision of people who take an "early" retirement in their late $50 \mathrm{~s}$ is fundamentally different from the migration decisions for the aged (age 85+). The "youngerold" (typically classified as 55-65) will tend to be healthier, more active, and independent than the "aged-old" (typically classified as over 85). The traditional logic is that the younger-old will be seeking recreational opportunities while the aged-old will be more concerned with access to health care facilities. To test these ideas, we look at migration across four age classifications: 55-64, 65-74, 75-84, and 85+. By looking at the stability 
across the four classifications, we can gain insights into how migration decisions vary across age groups. ${ }^{1}$

This research is presented in four additional sections beyond these introductory comments. In the next section, we provide a literature review of previous findings on migration patterns and then focus on older people and their flows. We also review the growing importance of amenities as a predictive element in migration studies and the construction of indexes to measure these factors. We then outline the conceptual issues, research methods, data, and measurements. We also describe the application of Geographically Weighted Regression (GWR) as an alternative approach to view the question at hand. Finally we present the empirical findings, and the implications between older migration and migration as a development policy are explored. Also discussed are some of the research limitations and areas of further study.

\section{LITERATURE REVIEW}

Three distinct literatures are drawn upon for this applied research. The first is the literature that focuses on the migration decisions and patterns of older people, while the second focuses on the role of amenities in migration patterns. The third outlines the research background for additional control variables. Each will be discussed in turn, and a summary of key studies is provided in Table 1.

\subsection{Migration of Older people}

While the baby boom generation is currently in middle age, the preponderance of this cohort will be reaching retirement age in the next decade and will become more mobile as they are no longer constrained by workplace obligations. Clark, Knapp, and White (1996) noted that projections from the 1990 Census indicate that by the year 2030, the portion of the population aged 65 and older will double current levels to approximately 22 percent of the population. ${ }^{2}$ The Economist (2004) noted that globally the proportion of people aged 60 or over will surpass the proportion of people under five; for the rest of history there are unlikely ever again to be more toddlers than grey-haired individuals. These trends, while tempered by some researchers such as Newbold (1996) and Cromartie (2004), illustrate the growing portion of the population that is reaching retirement age. If the number of retirees is indeed increasing, the questions that can be posed are: 1) are they moving? 2) why are they moving? and 3) where are they moving? We focus on the last question.

\footnotetext{
${ }^{1}$ In this literature, migrating older people have been referred to as both "retirees" and "elderly." Clearly not all older people are "elderly," nor are they all retired as many remain in the labor force, nor are all retirees elderly. While we are sensitive to the important differences in the use of these terms, in this work we use the words "retiree," "older people," and "elderly" synonymously.

${ }^{2}$ The level of that increase depends on assumptions made about increased life expectancy, but the idea that an increasing proportion of the population will be above 65 should be undeniable.
} 
TABLE 1

Conway \&

Houtenville

(1998)

Meyer

(1987)
State-level gross migration data for individuals over 65 , from 1985-1990

Net migration rates for young and old elderly in New England (19401980)

Selected Studies and Results

\begin{tabular}{|c|c|c|c|c|}
\hline $\begin{array}{c}\text { Variable } \\
\text { Type }\end{array}$ & Author & Migration Data & Hypotheses & Key Findings \\
\hline Age & $\begin{array}{l}\text { Conway \& } \\
\text { Houtenville } \\
(2003)\end{array}$ & $\begin{array}{l}\text { U.S. Census } \\
\text { migration flow data }\end{array}$ & $\begin{array}{l}\text { Examine differences in } \\
\text { migration behavior in younger } \\
\text { and older elderly. }\end{array}$ & $\begin{array}{l}\text { Patterns of migration and factors that affect } \\
\text { migration decisions differ between the younger } \\
\text { and older elderly. }\end{array}$ \\
\hline \multirow[t]{4}{*}{$\begin{array}{l}\text { Economic } \\
\text { Characteristics }\end{array}$} & $\begin{array}{l}\text { Clark \& } \\
\text { Hunter } \\
(1992)\end{array}$ & $\begin{array}{l}\text { Age-specific net } \\
\text { migration rates by } \\
\text { county for white } \\
\text { males, } 1970-1980\end{array}$ & $\begin{array}{l}\text { Examine impact of human } \\
\text { capital, public goods, and } \\
\text { site-specific amenities in } \\
\text { context of a life-cycle } \\
\text { framework. }\end{array}$ & $\begin{array}{l}\text { Amenities consistently found to influence } \\
\text { middle-aged and older males more than younger } \\
\text { cohorts, older cohorts reluctant to migrate to } \\
\text { areas of relatively high taxes, notably inheritance } \\
\text { and estate taxes. }\end{array}$ \\
\hline & $\begin{array}{l}\text { Duncombe } \\
\text { et al. }(2000)\end{array}$ & $\begin{array}{l}1990 \text { county-to- } \\
\text { county flows }\end{array}$ & $\begin{array}{l}\text { Examine influence of fiscal } \\
\text { tools on retirement } \\
\text { destinations. }\end{array}$ & $\begin{array}{l}\text { Taxes and expenditures have statistically } \\
\text { significant effect on locational choices-taxes } \\
\text { discourage migration, expenditures have mixed } \\
\text { effect, depending on service. Inheritance, } \\
\text { income, and property tax had largest relative } \\
\text { impacts. Results suggest, though, that states } \\
\text { should focus on marketing amenities rather than } \\
\text { using fiscal policy. }\end{array}$ \\
\hline & $\begin{array}{l}\text { Conway \& } \\
\text { Houtenville } \\
(1998)\end{array}$ & $\begin{array}{l}\text { State-level gross } \\
\text { migration data for } \\
\text { individuals over } 65 \text {, } \\
\text { from } 1985-1990\end{array}$ & $\begin{array}{l}\text { Examine whether elderly } \\
\text { migrate to states with } \\
\text { government policies that treat } \\
\text { them favorably. }\end{array}$ & $\begin{array}{l}\text { Educational spending, general spending, crime, } \\
\text { climate, and state's reliance on property and } \\
\text { income taxes are all important in migration } \\
\text { decisions of elderly. }\end{array}$ \\
\hline & $\begin{array}{l}\text { Meyer } \\
(1987)\end{array}$ & $\begin{array}{l}\text { Net migration rates } \\
\text { for young and old } \\
\text { elderly in New } \\
\text { England (1940- } \\
1980)\end{array}$ & $\begin{array}{l}\text { Examine the determinants of } \\
\text { migration in New England } \\
\text { states. }\end{array}$ & $\begin{array}{l}\text { Tourism employment provides an indication of } \\
\text { attractive locales for elderly who wish to locate } \\
\text { for recreation opportunities for young elderly in } \\
\text { all decades and old elderly in later decades. }\end{array}$ \\
\hline
\end{tabular}




\begin{tabular}{|c|c|c|c|c|}
\hline $\begin{array}{c}\text { Variable } \\
\text { Type }\end{array}$ & Author & Migration Data & Hypotheses & Key Findings \\
\hline \multirow[t]{2}{*}{$\begin{array}{l}\text { Demographic } \\
\text { Characteristics }\end{array}$} & $\begin{array}{l}\text { Newbold } \\
\text { (1996) }\end{array}$ & $\begin{array}{l}\text { PUMS data from } \\
1990 \text { U.S. Census } \\
\text { for individuals, } \\
1985-1990\end{array}$ & $\begin{array}{l}\text { Examine return and onward } \\
\text { interstate migration pattern of } \\
\text { elderly } 65 \text { and over. }\end{array}$ & $\begin{array}{l}\text { Study revealed that both return and onward } \\
\text { migrants sensitive to amenity factors and racial } \\
\text { similarity. Level of education and marital status } \\
\text { also were among individual characteristics that } \\
\text { influenced migration. }\end{array}$ \\
\hline & Choi (1996) & $\begin{array}{l}\text { Longitudinal } \\
\text { Survey of Aging } \\
\text { (LSOA), 1984- } \\
1990\end{array}$ & $\begin{array}{l}\text { Examine determinants of } \\
\text { migrants aged } 70 \text { and older. }\end{array}$ & $\begin{array}{l}\text { In the survey of over } 7,000 \text { elderly, more than } \\
30 \% \text { mentioned their own poor health, spouse's } \\
\text { poor health, or death as reasons for moving. }\end{array}$ \\
\hline \multirow[t]{2}{*}{$\begin{array}{l}\text { Natural } \\
\text { Amenities }\end{array}$} & $\begin{array}{l}\text { Graves } \\
(1980)\end{array}$ & $\begin{array}{l}49 \text { SMSAs } \\
\text { examined by age, } \\
\text { race, sex from } \\
1965-1970\end{array}$ & $\begin{array}{l}\text { Examine assumption that } \\
\text { utility differentials are solely } \\
\text { represented by economic } \\
\text { variables, namely income and } \\
\text { unemployment. }\end{array}$ & $\begin{array}{l}\text { Income and unemployment are compensation for } \\
\text { location-fixed goods, primarily climate but could } \\
\text { be extended to include other natural amenities as } \\
\text { well as man-made ones. }\end{array}$ \\
\hline & $\begin{array}{l}\text { Haas \& } \\
\text { Serow } \\
(1993)\end{array}$ & $\begin{array}{l}\text { Survey of } 586 \\
\text { migrants to western } \\
\text { North Carolina }\end{array}$ & $\begin{array}{l}\text { Examine heuristic model of } \\
\text { retirement migration process. }\end{array}$ & $\begin{array}{l}\text { Two groupings of amenities uncovered: } \\
\text { environmental amenities as well as activity } \\
\text { amenities (recreation and cultural attractions). } \\
\text { Financial issues were less important than either } \\
\text { amenity grouping in push or pull factors. Also } \\
\text { noted were that pull factors (factors drawing } \\
\text { people to an area) were more salient than push } \\
\text { factors (those triggering migration). }\end{array}$ \\
\hline
\end{tabular}

factors (those triggering migration). 
There are innumerable reasons and patterns to individuals' migration. When abrupt changes occur in a person's career pattern or family structure, there is a strong likelihood of moving (Wieseman and Roseman 1979; Litwak and Longino 1987). Events such as graduation, marriage, promotion, or retirement tend to have higher incidences of relocation. With the exception of retirement, triggering mechanisms do not correspond well with chronological age (Wieseman and Roseman 1979). He and Schachter (2003) noted, however, that the majority of older people did not move between 1995 and 2000. Of the 34.7 million people aged 65 and older who lived in the U.S. in 1995 through 2000, only 7.9 million lived in a different residence at the end of the five-year period. Among those who moved, the majority were within the same county (59.7 percent); the remainder (40.3 percent) was almost equally split between those moving to a different county in the same state and those moving to a different state. Despite these low numbers, communities continue to pursue retirees as a development strategy (Duncombe, Robbins, and Wolf 2000; Isserman 2001; Stallman and Siegel 1995). Long noted as the "grey peril" (Haas 1990, Isserman 2001), this growing proportion of the U.S. population provides a demographic source of opportunity for rural America. Many studies have shown that the retired create jobs when they move to an area and spend their retirement pensions, social security income, and savings (Deller 1995; Green et al. 1996; Shields, Stallmann, and Deller 2003;). As noted by Haas (1990), the "grey peril" could be viewed as "grey gold" and be a viable source of economic growth and development for some rural areas.

Within this group of individuals 65 and older are subgroups of people who move for different reasons. Many studies have challenged the notion of treating older migrants as a homogenous group (Meyer and Spear 1985; Wiseman and Roseman 1979; Choi 1996; Meyer 1987; Litwak and Longino 1987; Newbold 1996; Plane and Heins 2003). Litwak and Longino (1987) noted that there are three kinds of moves among older people: when they retire, when they experience moderate forms of disability, and when they experience major forms of chronic disability. Choi (1996) assigned ages and found that there appear to be two peaks of moving among older people: one just after retirement, between 60-69, and the other later, beyond the age of 70 . Newbold (1996) supported the idea that younger (65-69) and older (75+) individuals migrate for different reasons. This is not to say that all retirees fit these descriptions, but only that delineations should be made when examining older migration as they may respond differently to locational incentives.

Why then do older people migrate? Studies have shown a variety of influential variables. States with high tax shares, specifically property and income, have been shown to discourage in-migration and encourage out-migration (Conway and Houtenville 1998, 2003; Duncombe, Robins, and Wolf 2000; Clark, Knapp, and White 1996). Hospital and health care expenditures have an increased effect in attracting older migrants (Conway and Houtenville 2003; Choi 1996; Haas and Serow 1993). In almost all of these studies, amenity variables were shown to be significant to the migration decisions of older people (Conway and Houtenville 1998, 2003; Duncombe, Robbins, and Wolf 2000; Meyer and Speare, 1985; Choi 1996; Haas and Serow 1993; Plane and Heins 2003). 


\subsection{Amenities and Migration}

The definition of "amenities" lies in the climatic conditions or the stock of natural resources (i.e., forests, lakes, rivers, etc.) present in a region. We follow the concepts of amenities offered by Shaffer, Deller, and Marcouiller (2004) and expanded upon by Green, Deller, and Marcouiller (2005) to include both marketed and nonmarketed goods. We broadly define amenities as "qualities of a locality that make it an attractive place to live and work." This broadens the definition to include both traditional climatic and recreational areas as well as historic sites, social institutions, and cultivated landscapes.

Amenity migration is changing the face of rural America. Beale and Johnson (1998) found that growth in recreational counties has exceeded that in other nonmetro as well as metro areas. For the 24 years examined in their study, net migration accounted for most of the population growth in such counties. For Clark and Hunter (1992), amenity and fiscal factors remained important even after labor market opportunities were controlled for. Greenwood and Hunt (1989) tempered this claim with their finding that jobs and wages are more important than location-specific amenities in explaining net metropolitan migration of employed persons, though they mentioned that value of amenities could be captured in wages or rents through a Roback-type model (Roback 1982). Long and Hanson (1979) found that 57 percent of interstate movers aged 20 to 54 did so explicitly for employment related reasons, and an additional 11 percent were indirectly related to employment reasons, for example, college. For those aged 55 and over, only 14 percent moved explicitly for employment reasons, 32 percent moved for retirement/climate reasons, and 33 percent moved for family-related reasons.

For those individuals in their retirement years, amenities have repeatedly been found to have a positive impact, though this depends on the stage of retirement of the individual, as noted by Meyer and Speare (1985). In their study of Rhode Island residents, they found that assistance mobility increases with age while amenity mobility decreases. Clark and Hunter (1992) also found that amenity migration is more likely for younger retirees as increases in sunshine increased migration for those aged 60-74. Improved retirement income and increasing life expectancy have led the young elderly, those younger than 70 , to migrate to areas of leisure lifestyle (Choi 1996). In a survey of 500 older migrants in North Carolina, Haas and Serow (1993) showed that environmental amenities of scenic beauty were important pull factors, with recreational opportunities and cultural amenities the next most important reasons for being drawn to an area.

While these recent studies have shown the importance of natural amenities as an influence on migration, they have not provided a clear idea as to how these amenities could be used as a development tool, with the exception of perhaps Goe and Green (2005). Multiple studies have shown that amenities play a role in influencing migration decisions. Few if any explore the use of these as development tools. Granted, many rural areas have little control over climatic variables. As already noted, there are many other aspects to the amenity attributes of rural areas. The use of public policy tools has been explored for attracting older migrants and the general population. The amenity measures 
in this research are constructed in the hopes of leading to a more policy-oriented interpretation. The distinction between developed amenities such as recreational facilities and undeveloped amenities such as natural stocks of land, water, and forests among others is an important one for this research. The developed amenities are more suited to change and can be planned and acted upon (Dissart 2003). Outdoor recreation might stimulate economic activity and is more suited to planning and development than amenity stocks.

\subsection{Other Location-Specific Attributes}

In addition to amenities, the migration processes of older people depend on a variety of demographic characteristics. The total volume of migration to and from an area is strongly influenced by the size of an area's population. Similarly, states with a larger older population are more likely to attract older migrants, given the greater availability of services for older people (Newbold 1996). The latter effect is akin to agglomeration economies associated with a concentration of older people. Education is generally found to be positively related to in-migration (Cadwallader 1992). Higher levels of education reflect a greater knowledge to gather and process information (Long 1989). For older migrants, there is growing anecdotal evidence of an attraction to places with universities because of the amenities they provide. We suggest that education levels of a region or county for our study can serve as a proxy for certain amenities.

Crime rates have also received attention in the literature focusing on the migration of older people as they indicate a declining county or a county with significant social issues (Duncombe, Robbins, and Wolf 2000). The rates are also used as a measure of personal safety. Crime is often associated as a triggering mechanism for migration (Wiseman and Roseman 1979). It measures dissatisfaction with the residential environment through declines in safety or attractiveness. Duncombe, Robbins, and Wolf (2000) tried to capture the most visible crimes by using a measure of violent crime rate. They noted that crime results are often counterintuitive, with higher crime rates attracting older migrants. To address this, they included both the violent crime rate and its square to capture the potential for nonlinearity. The results were that both variables were significant for most groups, indicating that crime becomes a deterrent only for the highest crime rates.

As older people age, their demand for health services is likely to increase. This is often referred to as the "grey peril," where a growing older population places a drain on local health services. Studies have included an array of variables to measure this effect, from the number of physicians and number of hospital beds to the number of nursing home beds. Hospital and health care expenditures have a positive effect in attracting the older elderly and is used as evidence of the "grey peril" (Conway and Houtenville 2003; Choi 1996; Haas and Serow 1993). But Duncombe, Robbins, and Wolf (2000) cited one consistent result that the higher number of nursing homes repels rather than attracts new interstate migrants. Walters (1994) found the evidence on health care services to be mixed, with an equal number of studies showing insignificant and counterintuitive results to those that show areas with higher availability of health services to attract the aging elderly. 
Besides these demographic characteristics, a broad range of economic variables may effect migration decisions. By providing services, local governments also play a role in migration patterns (Cebula 1980). Duncombe, Robbins, and Wolf (2000) found that taxes and expenditures had a statistically significant impact on the migration decisions of retirees. Clark and Hunter (1992) found that young retirees avoided counties in states with high inheritance and estate taxes. Over 20 states have significantly reduced death and gift tax burdens since 1985 as they were viewed as a deterrent to migration or a catalyst for out-migration (Duncombe, Robbins, and Wolf 2000). In general, the effect of higher tax burdens, holding all else constant, should be easily recognized. Areas with higher relative tax shares should have reduced in-migration to those locations. This generalization is complicated by the fact that municipalities have at their disposal a variety of taxes that may have a greater or lesser impact on the movement of older people. Studies have found that higher property taxes make a place less appealing (Conway and Houtenville 1998, 2003; Duncombe, Robbins, and Wolf 2000; Clark, Knapp, and White 1996). Other taxes that have been found to be a deterrent to the migration of older people are inheritance and estate taxes (Clark and Hunter 1992; Clark, Knapp, and White 1996; Voss, Gunderson, and Manchin 1988).

Migration is also affected by local government services, commonly measured by public expenditures. Clark and Hunter (1992) divided local expenditure items into three categories: per capita expenditures on welfare and health services and per pupil expenditures on education. Conway and Houtenville (1998) attempted the same differentiation of expenditures using education, public welfare, health and hospital, and all other expenditures. In Conway and Houtenville's (2001) analysis of state fiscal policy, they found that in regard to education, expenditures seem to have an insignificant effect, suggesting that little utility is derived from education and that perhaps older migrants are reacting only to the taxes that fund these programs. This result contrasts with Conway and Houtenville (1998), who found significant negative coefficients associated with education spending; and to Clark and Hunter (1992), who found that expenditures on education increased inmigration. Conway and Houtenville $(2001,2003)$ also found health/hospital expenditures to have significant negative effect, and it is unclear whether the origin or destination effect is larger. The literature also suggests that older migrants avoid states that have higher welfare expenditures (Clark and Hunter 1992; Conway and Houtenville 2001). Residual expenditures used by Conway and Houtenville $(1998,2001,2003)$ were found to be the only expenditure variable that had a positive effect on migration.

Public sector measures present some problems. Public expenditures reflect both quality and cost of providing public services. Per capita revenues do not accurately reflect tax rates, and benefits are not precisely measured by per capita expenditures (Charney 1993). In addition, Conway and Houtenville (2001) cautioned against this enthusiasm for the local adoption of these policies in recognizing that fiscal policy may effect retirement migration but not as definitively as past studies suggest. Finally, we suggest that older migrants identifying with a particular race are attracted to areas that have a similar racial population (Newbold 1996). 


\section{EMPIRICAL METHODS}

Geographically Weighted Regression (GWR) is a recent modeling technique for spatial analysis developed by Fotheringham, Brunsdon, and Charlton (2002). It has been applied in a handful of studies such as a study of crime in London, Ontario, by Malczewski and Poetz (2005), commuting patterns in Ireland (Lloyd and Shuttleworth (2005), spatial patterns in school performance (Fotheringham, Charlton, and Brunsdon 2001), rural employment in the U.S. (Partridge, Rickman, Ali, and Olfert 2008), rural poverty patterns (Partridge and Rickman 2007), and migration in Japan (Nakaya 2001). This model extends previous models of spatial inquiry by allowing the explanatory variables effect to change over geographical space rather than assuming that the variable has the same influence over all locations. In the context of this research, a GWR model will be used to investigate spatial variation in the factors that influence the migration decision of older people. The GWR model specification can be expressed as:

$$
y_{i}=\beta_{0}+\sum_{k} \beta_{k} X_{i k}+\varepsilon_{i}
$$

or more generally as:

$$
y_{i}=\beta_{0}\left(u_{i}, v_{i}\right)+\sum_{k} \beta_{k}\left(u_{i}, v_{i}\right) x_{i k}+\varepsilon_{i},
$$

where $\left(u_{i}, v_{i}\right)$ indicates that location of the $i$ th point and $\beta_{k}\left(u_{i}, v_{i}\right)$ is a realization of the function $\beta_{k}(u, v)$ at point $i$. GWR recognizes that spatial variations in the parameters might exist and provides the model with a way that they can be recognized.

An issue that can be raised is that in equation (2) there are more unknowns than observed variables. Fotheringham, Brunsdon, and Charlton (2002) acknowledged this and noted that they do not consider the coefficients to be random; rather they view them as a function of locations in space. In this model, the data closer to location $i$ are weighted more heavily in the estimation than those further from $i$. The model is very similar to weighted least squares in its operation. The weighting scheme can be written as follows:

$$
\hat{\beta}\left(u_{i}, v_{i}\right)=\left(\mathbf{X}^{\prime} \mathrm{W}\left(u_{i}, v_{i}\right) \mathbf{X}\right)^{-1} \mathbf{X}^{\prime} \mathrm{W}\left(u_{i}, v_{i}\right) y,
$$

where the estimates are weights according to the $n$ by $n$ matrix $\mathrm{W}\left(u_{i}, v_{i}\right)$, whose off diagonal elements are zero and the diagonal elements are the weighting of each of the $n$ observations for regression point $i$.

This can be more clearly explained by considering the OLS equation $\mathbf{Y}=\beta \mathbf{X}+\varepsilon$, where the $\beta$ vector of parameters is estimated by

$$
\hat{\beta}=\left(\mathbf{X}^{\prime} \mathbf{X}\right)^{-1} \mathbf{X}^{\prime} \mathbf{Y}
$$

The GWR extension of this is 


$$
\mathbf{Y}=(\beta \otimes \mathbf{X}) 1+\varepsilon
$$

where each element of $\beta$ is multiplied by the corresponding element of $\mathbf{X}$. The matrix $\beta$ now has $n$ sets of parameters and the following form:

$$
\beta=\left(\begin{array}{ccc}
\beta_{0}\left(u_{1}, v_{1}\right) & \cdots & \beta_{k}\left(u_{1}, v_{1}\right) \\
\vdots & \ddots & \vdots \\
\beta_{0}\left(u_{n}, v_{n}\right) & \cdots & \beta_{k}\left(u_{n}, v_{n}\right)
\end{array}\right) .
$$

Each parameter above is then estimated using,

$$
\hat{\beta}(i)=\left(\mathbf{X}^{\prime} \mathrm{W}(i) \mathbf{X}\right)^{-1} \mathbf{X}^{\prime} \mathrm{W}(i) \mathbf{Y},
$$

where $i$ represents a row in the matrix in (7) and $\mathrm{W}(i)$ is an $n$ by $n$ spatial weighting matrix of the form

$$
\mathrm{W}(i)=\left(\begin{array}{cccc}
w_{i 1} & 0 & \cdots & 0 \\
0 & w_{i 2} & \cdots & 0 \\
\vdots & \vdots & \ddots & \vdots \\
0 & 0 & \cdots & w_{i n}
\end{array}\right)
$$

$w_{i n}$ is the weight given to data point $n$ for location $i$. The function for the weighting scheme is Gaussian, with the ith observation being defined as:

$$
w_{i j}=\exp \left[-\frac{1}{2}\left(\frac{d_{i j}}{b}\right)^{2}\right],
$$

where $d$ is the distance between observation $i$ and location $j$, and $b$ is the bandwidth estimated by minimizing the Akaike Information Criterion (AIC). The spatial weighting schemes in GWR can be made to adapt themselves to the size variations in the density of the data, larger bandwidths in sparser areas and smaller in more highly concentrated areas. The essential idea is that for each regression point $i$, there is an area of influence around $i$ described by the weighting function so that observations near $i$ have more weight in the estimation of the parameters than those further away. This will be used to highlight the degree of misspecification on the global model.

The technique of GWR allows us to investigate the migration patterns of older people in a way that allows the explanatory variables' influence to change over the geographical space rather than assuming it has the same structure at all locations. In addition, by allowing parameter values to vary by geographic location, one can visually map individual parameters within GIS. Such a visual representation provides a powerful means to 
better understanding the influence of the exogenous variables on, for example, crime patterns.

To test for stationarity of individual parameters across space, we will use Monte Carlo significance tests first suggested by Hope (1968). In this process the observed value of the test statistic is compared with $n-1$ simulated ones. The results are sorted, and the rank of the observed test statistic is determined. The $p$-value for the test is obtained by subtracting the ratio rank $/ n$ from unity. In this version of the GWR software, the number of local model calibrations is set to 100 . After the observed variance of the local parameter estimate is calculated and stored, 99 sets of variances are obtained for each variable based on different randomizations of the observed data. The $p$-value is then computed for the local parameters associated with each variable as described above. These $p$-values indicate whether the spatial variation is significant or it most likely occurred by chance.

\section{MODEL SPECIFICATION}

Many studies have challenged the treatment of older migrants as a homogenous group (Wiseman and Roseman 1979; Meyer and Speare 1985; Litwak and Longino 1987; Meyer 1987; Choi 1996; Newbold 1996; Conway and Houtenville 2003; Plane and Heins 2003). It seems reasonable to develop and identify subgroups of older migrants who are hypothesized to share characteristics and motivations. Litwak and Longino (1987) noted that there are three kinds of moves among retirees: when they retire, when they experience moderate forms of disability, and when they experience major forms of chronic disability. Choi (1996) assigned ages and found that there appeared to be two peaks of moving among older people: one just after retirement, between 60-69, and the other later, beyond the age of 70. Newbold (1996) supported the idea that younger (6569 ) and older $(75+)$ individuals migrate for different reasons. Clark, Knapp, and White (1996) used three age groupings, 55-64, 65-74, and those at least 75. The use of such delineation as it applies to this research will be discussed later in the study. The research seems to support the need to recognize that the younger elderly and older elderly may make different decisions on where to move and what attributes may influence those moves. We analyze the migration and location decisions of four groups of older people: $55-64,65-74,74-85$, and $85+$.

Given in- and out-migration flow data from the 2000 Census, two equations will be estimated - one for in-migration and the second for out-migration - for four sets of older migrants with the hope of determining what factors influence these decisions. In total, eight separate gross migration flow models will be estimated. We use three broad categories of factors to examine the flows of older migrants: demographic characteristics, economic characteristics, and quality of life/amenity characteristics. Unless otherwise noted, all explanatory variables reflect 1990 values. Ideally information would be available for 1995 , as we are examining gross migration flows from 1995-2000, but there is a lack of consistent data outside of the 1990 Census. 
The purpose of the demographic grouping of variables is to capture the basic characteristics of the population in each county. Seven variables are used to signify this grouping.

- County Population, 1995

- Percent of the population over age 65,1990

- Percent of the population not classified as white, 1990

- Percent of the population over age 25 with a Bachelor's Degree, 1990

- Total crime rate, 1990

- Active nonfederal physicians per 100K persons, 1990

- Percent of civilians employed in health services, 1990

The hypothesized sign for both the county populations as well as the percentage of the population that is $65+$ is expected to be positive for in-migration but negative for outmigration. An agglomeration effect is present, as communities of the elderly attract additional elderly (Conway and Houtenville 1998). Areas with higher levels of education are likely to show greater mobility; conversely, areas with lower levels of education are likely to be associated with lower levels of migration. With respect to race, people are less likely to move into areas where diversity is high. Stated another way, migrants identifying with a particular racial group are hypothesized to be drawn to areas with matching populations (Newbold 1996). The expected sign for crime is negative for in-migration and positive for out-migration. Crime is considered a negative amenity, a push factor, causing individuals to relocate (Gale and Heath 2000). The number of physicians and the percent of civilians employed in the health services both will have an increasing positive effect on in-migration as individuals' health becomes more fragile. The effect on outmigration will be increasingly negative as the health sector becomes more important.

Six economic characteristic variables are included in this study to examine the influence of the public/private sector and cost of living on gross migration flows.

- Property taxes as a percent of local tax revenue, 1986-1987

- Per capita total general government expenditures, 1986-1987

- Per capita employment in eating and drinking establishments, 1990

- Per capita employment in retail establishments, 1990

- Civilian unemployment rate, 1991

- Median value of owner-occupied housing, 1990

The sign for property taxes is expected to be negative: the higher the property tax rate the less willing people should be to move to the area (Duncombe, Robbins, and Wolf 2000). Likewise for out-migration property taxes are expected to have a positive effect as an increased tax rate will push people out. Expenditures are hypothesized to be positively related to in-migration and negatively to out-migration, suggesting that retirees are drawn to areas where services are better. Both industry variables are hypothesized to be positive. Both industries are associated with attractive locations that have been shown to have an 
influence the migration of older people (Meyer 1987). Unemployment along with the crime rate are viewed as indicators of a declining area (Duncombe, Robbins, and Wolf 2000). For this reason, it is expected to negatively impact in-migration and hold the opposite effect for out-migration. Median housing value is used to control for cost-ofliving differences (Clark and Hunter 1992). As a proxy for cost of living, older migrants are hypothesized to be repelled from high cost areas, so it would have a positive relationship with out-migration and a negative one with in-migration levels.

The final variable included in the analysis is a variable to explore where, in the transition from metro to rural areas, older people are migrating. These rural-urban continuum codes, or Beale codes, are a nine-part classification scheme that distinguishes the degree of urbanization in a county by the population of the county and its adjacency to a metro area. The code is not a perfectly progressive scale but runs from one to nine, with the largest urban counties taking on a value of one and the least populated, remote rural counties taking on a value of nine. The rural-urban migration patterns are changing as those nonmetro areas on the urban fringe are the fastest growing counties (Cromartie 1998). The Beale codes, in this case from 1993, are hypothesized to have a decreasingly positive impact as young retirees make amenity moves to rural areas; as they age, their focus shifts to more health-related moves.

For this study, principal component analysis will be used to capture the variation in a series of built amenities that we hypothesize will be captured in the following sets of recreation variables: (1) camping/picnicking facilities, (2) golf/tennis facilities, (3) waterbased recreation facilities, (4) hiking and outdoor recreational vehicle facilities, (5) tourist attractions, (6) amusement places, and (7) winter recreation facilities. We attempt to segregate the effects of an area's natural resource base and the type of development that occurs and to define more specific policy recommendations, if appropriate. We recognize that policy can do little to influence the presence of natural amenities, but it can have an impact on the recreational facilities in the area.

The aggregate factor approach attempts to reduce this wide array of amenity attributes and combine them into similar groupings. Principal component and factor analysis are the two most commonly used procedures. ${ }^{3}$ The process is essentially a method of compressing a large set of related variables into a single measure (Deller et al., 2001; Deller and Lledo 2007). English, Marcouiller, and Cordell (2000) used principal component analysis to create four sets of indexes: water, winter, land, and urban resources. The components were used as part of an examination of the effect of amenity-based tourism on rural counties. Using five similarly constructed indexes (climate, land, water, winter, and recreational infrastructure) Deller et al. (2001) found that counties with higher levels of amenity endowments experienced higher levels of economic growth. Goe and Green (2005) examined the influence of several factors, including amenities, on nonmetropolitan well-being. They created six indices using principal component analysis. The level of

\footnotetext{
${ }^{3}$ For a detailed discussion of the use of principal component analysis for the construction of amenity and quality of life indices see $\mathrm{Ng}$ and Gunderson (2006).
} 
amenities was found to have a positive impact on the absolute level of well-being. Nonmetropolitan areas with high levels of land-based natural amenities were shown to have experienced higher levels of inequality in the 20-year study period.

While the use of principal components to build amenity indices has become more widespread in the literature, there are serious limitations. First and foremost, the final measures (factor scores or principal components) are not easily interpreted (Kim 2002). Despite the apparent attractiveness of allowing the data to craft a single index, the index does not lend itself to a direct interpretation of the original variables comprising the index. Ferguson et al. (2007) were critical of the use of principal components in the construction of amenity measures. They correctly pointed out that the final principal component index does not allow the researcher to identify the individual elements that are driving the final model results and that important variations in the original data are lost to the GWR analysis. In their study of Canadian population change, they concluded that the loss of variation in the original data greatly reduced the predictive power of their models. Consistent with the findings of $\mathrm{Ng}$ and Gunderson (2006), great care must be taken when building individual factor indices. Based on our prior research, it is better to err on the side of compressing fewer variables into principal component derived indices and include more indices in the final model specification.

Data for the analysis is for 3,072 contiguous U.S. counties and comes from a range of sources, including BEA-REIS, City and County Data Book, and the NORSIS data set maintained by the USDA Forest Service. ${ }^{4}$ The National Outdoor Recreation Supply Information System (NORSIS) data set is developed and maintained by the USDA Forest Service's Wilderness Assessment Unit, Southern Research Station, Athens, Georgia. As an outflow of the 1998 Resource Planning Act Assessment of Outdoor Recreation and Wilderness, the FS maintains an extensive county-level data set documenting facilities and resources that support outdoor recreation activities. Many of these same resources are precisely the amenities that contribute to the overall quality of life of the region. The data set has 3,116 observations and 492 variables. Each of the 492 variables was derived from a source dataset and aggregated to the county level. Many of these are then sum totals of types of land or water acreage in the county or sum totals of recreation facility counts. Agency sources include the USDA Forest Service, the National Park Service, U.S. Army Corps of Engineers, Bureau of Land Management, U.S. Fish \& Wildlife Service, Bureau of Reclamation, and the Tennessee Valley Authority, to name a few. The migration data was derived from the U.S. Census Migration DVD from Census 2000, which included county-to-county flows.

The results of the principal component construction for an area's built amenities are presented in Tables 2 through 8. In Table 2, the Nature component, 14 variables representing an area's camping and picnicking facilities are combined into this single index. As described previously, the size of the eigenvector can be understood as the relative

\footnotetext{
${ }^{4}$ Several counties in Virginia had to be dropped over the course of the analysis as data values for some of the variables were unavailable for those counties.
} 
weight that the variable contributes to the final index. The Nature index captures 24.85 percent of the variation in the 14 separate measures. The Clubs index (Table 3) explains 68.04 percent of the variation in the number of public/private golf and tennis courts present in a county. The Water index (Table 4) captures primarily the number of boating opportunities within the county through marinas and boat ramps as well as the presence of fishing opportunities. Only 19.56 percent of the variation in these water-based recreational measures is explained by this index. This is, as was the case with the Nature index, perhaps due to the large number of variables included in the analysis. The Land index (Table 5) is a combination of measures of the number of trailhead, trails, and trail miles and comes from the National Park Service, the Bureau of Land Management, the USDAForest Service, and the U.S. Army Corp of Engineers. It only accounts for 19.20 percent of the variation. The Tourism index (Table 6) is intended to capture the more cultural side of tourist activities, including museums and historic sites. The index explains 60.42 percent of the total variation. The Amusement index (Table 7) captures amusement places; 71.08 percent of the variation is explained by the index. The final index, Winter Use, loads snowmobiling and skiing opportunities. Cross-country and snowmobiling measures are not loaded into the index, but downhill ski variables as measured by InterSki Service, Inc. (ISS) loads heavily (Table 8). As previously mentioned, the regression results of each of these amenity sets are discussed in the results section.

In addition to the principal component indices measuring the man-made stocks of amenities, several indices are created for the natural amenity stocks to describe the land forms and cover are present in each county. Following Dissart (2003) we retained these variables for the analysis.

- Average temperature, standardized

- Average annual snowfall, standardized

- Land area classified in water acreage, standardized

- Land area classified in mountainous acreage, standardized

- Land area classified in forested acreage, standardized

- Land area classified in cropland, pasture, and range acreage, standardized

- Land area classified in wetland acreage, standardized

- Land area classified in federal, non-federal wildlife acreage, standardized

To define counties in terms of their physical environment, each category was defined as a proportion of total land area. All ratios were then expressed as percentages. The principal components - the proportions listed above - and the two climate variables - snowfall and average temperature-were all standardized to a mean zero and a standard deviation of one. 
TABLE 2

Principal Component Eigenvectors: Nature

Nature Variables

Eigenvector

USDA-FS, \# tent sites (1987)

0.4311

USDA-FS, \# trailer sites (1987)

0.4184

NPS, \# units with camping

0.2568

COE, \# individual campsites

0.0420

BLM, \# campgrounds

0.2359

State park, \# campsites

0.2469

WOODALLS, \# public campground sites

0.2180

WOODALLS, \# private campground sites

0.2096

USDA-FS, \# picnic areas (1987)

0.3933

NPS, \# units with picnicking

0.2429

COE, \# individual picnic sites

0.0624

BLM, \# picnic areas

0.2472

State parks with picnicking available

0.2714

ABI, \# picnic grounds

0.1042

Percent of Total Variance Explained

0.2485

TABLE 3

Principal Component Eigenvectors: Clubs

\begin{tabular}{lc}
\hline Country Club Variables & Eigenvector \\
\hline ABI, \# private golf courses & 0.4462 \\
ABI, \# public golf courses & 0.4789 \\
ABI, \# golf practice ranges & 0.4722 \\
ABI, \# private tennis courts & 0.4535 \\
ABI, \# public tennis courts & 0.3779 \\
\multicolumn{1}{c}{ Percent of Total Variance Explained } & 0.6804 \\
\hline
\end{tabular}


TABLE 4

Principal Component Eigenvectors: Water

\begin{tabular}{lc}
\hline Water Variables & Eigenvector \\
\hline ABI, \# boat rental firms & 0.3941 \\
ABI, \# marinas with $<5$ employees & 0.4352 \\
ABI, \# marinas with 5-9 employees & 0.4389 \\
ABI, \# marinas with 10+ employees & 0.4355 \\
Marinas per 1K population & 0.2250 \\
COE, \# boat ramps & 0.0358 \\
BLM, \# boat launches & 0.0025 \\
NPS, \# units with boating & 0.1195 \\
USDA-FS, \# boat ramps (1987) & 0.0326 \\
State parks with boating available & 0.2206 \\
State parks with marina available & 0.1236 \\
ABI, \# fishing piers & 0.1734 \\
ABI, \# private fishing lakes & 0.0102 \\
ABI, \# public fishing lakes & -0.0056 \\
ABI, \# fishing lakes and ponds & 0.0492 \\
NPS, \# units with fishing & 0.1404 \\
State parks with fishing available & 0.2516 \\
COE, \# fishing docks/piers & 0.0184 \\
ABI, \# bathing beaches & 0.1582 \\
USDA-FS, \# developed swimming areas (1987) & 0.0276 \\
\multicolumn{1}{c}{ Percent of Total Variance Explained } & 0.1956 \\
\hline
\end{tabular}

\section{TABLE 5}

Principal Component Eigenvectors: Land Use

\begin{tabular}{lc}
\hline Land Use Variables & Eigenvector \\
\hline NPS, \# units with hiking & 0.0135 \\
State park miles of hiking trails & 0.1694 \\
BuRec, \# areas with hiking trails & -0.0275 \\
COE, miles of hiking trails & 0.4398 \\
USDA-FS, miles road open to public (1987) & 0.0084 \\
COE, miles of off-road vehicle trails & 0.2350 \\
BuRec, \# areas with ORV trails & -0.0093 \\
USDA-FS, \# trailheads (1987) & 0.0045 \\
COE, \# trails & 0.5456 \\
COE, miles of other trails & 0.4125 \\
COE, miles of interpretive trails & 0.5002 \\
BLM, \# trailheads & -0.0025 \\
BuRec, \# areas with nature trails & -0.0272 \\
RTC, total rail-trail miles & 0.0528 \\
\multicolumn{1}{c}{ Percent of Total Variance Explained } & 0.1920 \\
\hline
\end{tabular}


TABLE 6

Principal Component Eigenvectors: Tourism

\begin{tabular}{lc}
\hline Tourism Variables & Eigenvector \\
\hline ABI,\# amusement /entertainment tourist attractions & 0.4678 \\
ABI, \# historic/cultural tourist attractions & 0.5363 \\
ABI, \# natural res. tourist attractions & 0.4733 \\
ABI, \# museums & 0.5192 \\
Percent of Total Variance Explained & 0.6042 \\
\hline
\end{tabular}

TABLE 7

Principal Component Eigenvectors: Amusement

\begin{tabular}{lc}
\hline Amusement Variables & Eigenvector \\
\hline ABI, \# amusement places & 0.6685 \\
ABI, \# miniature golf firms & 0.6604 \\
Amusement places per 1K population & 0.342 \\
Percent of Total Variance Explained & 0.7108 \\
\hline
\end{tabular}

TABLE 8

Principal Component Eigenvectors: Winter Use

\begin{tabular}{|c|c|}
\hline Winter Use Variables & Eigenvector \\
\hline NPS, \# units with snowmobiling & 0.0928 \\
\hline State parks with snowmobiling available & 0.1123 \\
\hline BuRec, \# areas with winter sports & 0.0855 \\
\hline NPS, \# units with cross-country skiing & 0.1021 \\
\hline State park number of with $\mathrm{x}$-c skiing available & 0.1295 \\
\hline ISS, Skiable acreage & 0.4791 \\
\hline ISS, Skiable acreage $(\%)$ & 0.4404 \\
\hline ISS, \# destination resorts & 0.4105 \\
\hline ISS,\# downhill skiing areas & 0.3995 \\
\hline ISS, Average vertical drop at ski areas & 0.4389 \\
\hline Percent of Total Variance Explained & 0.3626 \\
\hline
\end{tabular}




\section{EMPIRICAL RESULTS}

Before turning to a discussion of our results, it is important to note that given the specification of our models, using both the OLS and GWR methods results in 480 individual coefficients. The results of the in-migration models are reported in Table 9 and the out-migration models are provided in Table 10. The OLS models perform reasonably well, with $R^{2}$ values ranging from 0.6862 for the in-migration of those aged $65-74$, to 0.9613 for the out-migration of the 55-64 grouping. One of the goals of this research is to compare the efficiency of the OLS models to that of the GWR models. In this case, the GWR estimates were more efficient than those of the OLS for all eight models. This is based on a comparison of the derived sum of squared residuals and the corresponding ANOVA F-statistic. The ANOVA tests the hypothesis that the GWR model measures no significant improvement over the global model. The results provide evidence and support for the assertion spatial dependency exists in the data and ranges from a low of 14.56 for the in-migration of the $85+$ model to a high of 33.05 for the in-migration of the 75-84 model. As expected, the GWR approach overall provides more efficient estimates.

A central interest of this study is the spatial variation in the coefficients provided by the GWR method. The results of the Monte Carlo simulations are reported in Table 11 for the in-migration models and Table 12 for the out-migration results. Based on Monte Carlo analysis, 43 of the 120 (35.8 percent) estimated coefficients in the in-migration models exhibit significant spatial variation. For the out-migration model, 49 (40.8 percent) of the coefficients exhibit significant spatial variation. Given the volume of results coupled with the mixture of global and spatial coefficients, we clearly can not discuss each result. Comparing in- and out-migration flows further complicates the discussion. It is not clear whether our results can be used to make inferences about net migration. A central hypothesis of our research is that the determinants of the migration of older people vary across age groups. Finally, we find evidence that global parameters (OLS) and median spatial parameters (GWR) flip signs, further complicating a detailed discussion of our results. Instead, we will look for patterns in the results and focus our attention on the results associated with the amenity variables.

In terms of our control variable, we find the following patterns. First, counties that tend to have a higher concentration of minorities experience higher levels of outmigration and lower levels of in-migration. Counties that have a higher concentration of older people have a higher level of both in- and out-migration. This result may be endogenous in the sense that counties with a greater concentration of older people will experience higher overall levels of older migration patterns. Crime rates tend to be associated with higher levels of both in- and out-migration. Somewhat unexpected, a higher concentration of doctors is associated with higher levels of out-migration and lower levels of in-migration. All else held constant, older migrants do not appear to relocate to have access to health care services. This result holds for even the oldest migrant classification. This result is counterintuitive and not consistent with the results of others (e.g., Oehmke, Tsukamoto, and Post 2007). Higher dependence on property tax does not appear to influence migration patterns of older people, but there is some evidence that 
TABLE 9

In-Migration 1995-2000

\begin{tabular}{|c|c|c|c|c|}
\hline & Age 55-64 & Age 65-74 & Age $75-84$ & Age $85+$ \\
\hline Intercept & $\begin{array}{c}621.6323 \\
(3.03) \\
{[-205.4999]}\end{array}$ & $\begin{array}{c}282.8443 \\
(1.73) \\
{[-222.7037]}\end{array}$ & $\begin{array}{c}244.7788 \\
(3.42) \\
{[47.7757]}\end{array}$ & $\begin{array}{c}89.0368 \\
(3.27) \\
{[30.0585]}\end{array}$ \\
\hline $\begin{array}{l}\% \text { of population over } 25 \text { with at least a } \\
\text { BA }\end{array}$ & $\begin{array}{c}-1.7589 \\
(0.33) \\
{[10.2590]}\end{array}$ & $\begin{array}{l}-8.2449 \\
(1.92) \\
{[0.3590]}\end{array}$ & $\begin{array}{l}2.0258 \\
(1.08) \\
{[5.8886]}\end{array}$ & $\begin{array}{l}3.0956 \\
(4.32) \\
{[3.9348]}\end{array}$ \\
\hline County Population, 1995 & $\begin{array}{l}0.001 \\
(7.73) \\
{[0.0013]}\end{array}$ & $\begin{array}{l}-0.0001 \\
(1.22) \\
{[0.0012]}\end{array}$ & $\begin{array}{l}0.0004 \\
(9.97) \\
{[0.0006]}\end{array}$ & $\begin{array}{c}0.0004 \\
(21.67) \\
{[0.0004]}\end{array}$ \\
\hline $\begin{array}{l}\% \text { of population not classified as } \\
\text { white }\end{array}$ & $\begin{array}{l}-4.7537 \\
(2.76) \\
{[-4.3013]}\end{array}$ & $\begin{array}{l}-3.9354 \\
(2.87) \\
{[-1.8300]}\end{array}$ & $\begin{array}{l}-1.7442 \\
(2.90) \\
{[-1.7077]}\end{array}$ & $\begin{array}{l}-0.3174 \\
(1.39) \\
{[-0.4366]}\end{array}$ \\
\hline $\begin{array}{l}\text { Median housing value, owner } \\
\text { occupied }\end{array}$ & $\begin{array}{l}0.0027 \\
(2.71) \\
{[0.0071]}\end{array}$ & $\begin{array}{l}0.0008 \\
(1.01) \\
{[0.0079]}\end{array}$ & $\begin{array}{l}0.0004 \\
(1.26) \\
{[0.0010]}\end{array}$ & $\begin{array}{l}0.0006 \\
(4.42) \\
{[0.0006]}\end{array}$ \\
\hline$\%$ of population over 65 & $\begin{array}{c}36.0994 \\
(5.86) \\
{[27.4497]}\end{array}$ & $\begin{array}{c}35.6311 \\
(7.27) \\
{[14.3081]}\end{array}$ & $\begin{array}{l}12.4365 \\
(5.79) \\
{[11.6850]}\end{array}$ & $\begin{array}{l}5.0332 \\
(6.16) \\
{[4.4762]}\end{array}$ \\
\hline \# crimes per 1,000 individuals & $\begin{array}{l}4.0041 \\
(3.29) \\
{[2.8471]}\end{array}$ & $\begin{array}{l}2.357 \\
(2.44) \\
{[0.3093]}\end{array}$ & $\begin{array}{l}0.6499 \\
(1.53) \\
{[0.5874]}\end{array}$ & $\begin{array}{l}0.1064 \\
(0.66) \\
{[0.0603]}\end{array}$ \\
\hline $\begin{array}{l}\text { \# physicians (active non-fed) per } \\
\text { 100K }\end{array}$ & $\begin{array}{l}-1.0571 \\
(3.81) \\
{[-0.8313]}\end{array}$ & $\begin{array}{l}-0.782 \\
(3.54) \\
{[-0.3166]}\end{array}$ & $\begin{array}{l}-0.3024 \\
(3.12) \\
{[-0.2476]}\end{array}$ & $\begin{array}{l}-0.0237 \\
(0.64) \\
{[-0.0454]}\end{array}$ \\
\hline $\begin{array}{l}\% \text { of civilians employed in health } \\
\text { services }\end{array}$ & $\begin{array}{c}-14.3882 \\
(1.48) \\
{[-6.1493]}\end{array}$ & $\begin{array}{l}-5.9269 \\
(0.77) \\
{[3.5362]}\end{array}$ & $\begin{array}{l}1.0711 \\
(0.32) \\
{[1.2960]}\end{array}$ & $\begin{array}{l}1.4508 \\
(1.12) \\
{[1.7014]}\end{array}$ \\
\hline $\begin{array}{l}\text { ERS Metro/Nonmetro status, Beale } \\
\text { code (1993) }\end{array}$ & $\begin{array}{c}-48.0374 \\
(4.28) \\
{[-40.7107]}\end{array}$ & $\begin{array}{c}-27.2194 \\
(3.05) \\
{[-20.3447]}\end{array}$ & $\begin{array}{c}-19.5695 \\
(5.00) \\
{[-16.8471]}\end{array}$ & $\begin{array}{c}-10.1645 \\
(6.83) \\
{[-7.5374]}\end{array}$ \\
\hline $\begin{array}{l}\text { Property tax level as \% of tax } \\
\text { revenues (1986-87) }\end{array}$ & $\begin{array}{l}-1.2428 \\
(0.86) \\
{[0.7166]}\end{array}$ & $\begin{array}{l}-0.6974 \\
(0.61) \\
{[0.1176]}\end{array}$ & $\begin{array}{l}-0.4266 \\
(0.85) \\
{[-0.0760]}\end{array}$ & $\begin{array}{l}-0.0915 \\
(0.48) \\
{[-0.0062]}\end{array}$ \\
\hline $\begin{array}{l}\text { County general expenditures (1986- } \\
87 \text { ) per } 1,000 \text { individuals }\end{array}$ & $\begin{array}{l}-0.0147 \\
(0.04) \\
{[-0.1200]}\end{array}$ & $\begin{array}{c}0.2049 \\
(0.68) \\
{[-0.1193]}\end{array}$ & $\begin{array}{l}-0.0433 \\
(0.33) \\
{[-0.0471]}\end{array}$ & $\begin{array}{l}-0.103 \\
(2.04) \\
{[-0.0806]}\end{array}$ \\
\hline $\begin{array}{l}\text { Number of jobs in eating \& drinking } \\
\text { establishments per capita }\end{array}$ & $\begin{array}{l}0.4536 \\
(0.39) \\
{[0.0535]}\end{array}$ & $\begin{array}{c}0.4953 \\
(0.54) \\
{[-0.2772]}\end{array}$ & $\begin{array}{l}-0.8073 \\
(2.00) \\
{[-0.8126]}\end{array}$ & $\begin{array}{c}-0.7446 \\
(4.85) \\
{[-0.6025]}\end{array}$ \\
\hline $\begin{array}{l}\text { Number of jobs employed in retail } \\
\text { sector per capita. }\end{array}$ & $\begin{array}{l}0.5605 \\
(0.40) \\
{[-0.0633]}\end{array}$ & $\begin{array}{l}0.7672 \\
(0.69) \\
{[0.5673]}\end{array}$ & $\begin{array}{l}0.7267 \\
(1.50) \\
{[0.6111]}\end{array}$ & $\begin{array}{c}0.2503 \\
(1.35) \\
{[0.1998]}\end{array}$ \\
\hline Unemployment rate, civilian (1991) & $\begin{array}{l}-4.0746 \\
(0.57) \\
{[5.2678]}\end{array}$ & $\begin{array}{l}1.8366 \\
(0.32) \\
{[2.6090]}\end{array}$ & $\begin{array}{l}0.0519 \\
(0.02) \\
{[3.3689]}\end{array}$ & $\begin{array}{c}-0.2644 \\
(0.28) \\
{[0.7079]}\end{array}$ \\
\hline
\end{tabular}


The Review of Regional Studies, Vol. 37, No. 3, 2007, pp. 303 - 343

\begin{tabular}{|c|c|c|c|c|}
\hline & Age $55-64$ & Age $65-74$ & Age $75-84$ & Age $85+$ \\
\hline \multirow[t]{3}{*}{$\overline{\text { Average temperature }}^{\dagger}$} & 206.361 & 176.8056 & 63.6571 & 14.2706 \\
\hline & $(5.72)$ & $(6.16)$ & $(5.05)$ & $(2.98)$ \\
\hline & [177.7439] & [51.0457] & [55.6373] & [11.1410] \\
\hline \multirow[t]{3}{*}{ Average annual snowfall ${ }^{\dagger}$} & -85.6604 & -69.2656 & -34.31 & -11.5061 \\
\hline & $(2.41)$ & $(2.45)$ & $(2.77)$ & $(2.44)$ \\
\hline & {$[-52.392]$} & {$[-43.6612]$} & {$[-32.3131]$} & {$[-16.9890]$} \\
\hline \multirow{3}{*}{$\begin{array}{l}\text { Proportion of county land area classified } \\
\text { in water acreage }\end{array}$} & -41.8725 & -49.3021 & -39.7418 & -22.0899 \\
\hline & $(1.66)$ & $(2.46)$ & $(4.52)$ & $(6.60)$ \\
\hline & [-38.7879] & {$[-28.7264]$} & {$[-34.3107]$} & {$[-17.71480]$} \\
\hline \multirow{3}{*}{$\begin{array}{l}\text { Proportion of county land area classified } \\
\text { in mountainous acreage }{ }^{\dagger}\end{array}$} & -10.2558 & 7.947 & -0.421 & -3.9637 \\
\hline & $(0.40)$ & $(0.39)$ & $(0.05)$ & $(1.16)$ \\
\hline & [1.1999] & {$[-4.6740]$} & {$[1.0437]$} & {$[-3.7520]$} \\
\hline \multirow{3}{*}{$\begin{array}{l}\text { Proportion of county land area classified } \\
\text { in forested acreage }\end{array}$} & -183.6093 & -143.9415 & -79.913 & -37.5284 \\
\hline & $(4.50)$ & $(4.43)$ & $(5.62)$ & $(6.93)$ \\
\hline & {$[-85.4125]$} & {$[-47.8872]$} & {$[-56.8571]$} & [-27.9449] \\
\hline \multirow{3}{*}{$\begin{array}{l}\text { Proportion of county land area classified } \\
\text { in cropland, pasture, and range } \\
\text { acreage }^{\dagger}\end{array}$} & -192.1632 & -120.5563 & -75.2264 & -40.8897 \\
\hline & (4.35) & $(3.43)$ & (4.89) & $(6.98)$ \\
\hline & {$[-124.9782]$} & {$[-70.5347]$} & {$[-57.4175]$} & {$[-32.4103]$} \\
\hline \multirow{3}{*}{$\begin{array}{l}\text { Proportion of county land area classified } \\
\text { in wetland acreage }\end{array}$} & 8.8952 & 20.6693 & 3.8625 & -1.6758 \\
\hline & $(0.36)$ & $(1.06)$ & $(0.45)$ & $(0.52)$ \\
\hline & {$[-2.3424]$} & {$[-8.0870]$} & [7.3259] & {$[0.3401]$} \\
\hline \multirow{3}{*}{$\begin{array}{l}\text { Proportion of county land area classified } \\
\text { in federal, non-federal wildlife } \\
\text { acreage }^{\dagger}\end{array}$} & 104.2589 & 111.9054 & 48.3169 & 17.817 \\
\hline & $(4.83)$ & $(6.52)$ & $(6.42)$ & $(6.22)$ \\
\hline & {$[59.7023]$} & [8.4696] & [36.5955] & {$[13.5150]$} \\
\hline \multirow[t]{3}{*}{ Nature index } & 95.3358 & 70.35 & 19.5322 & -2.0845 \\
\hline & $(6.63)$ & $(6.15)$ & $(3.90)$ & $(1.09)$ \\
\hline & {$[38.5050]$} & [1.7899] & [15.0799] & {$[0.4747]$} \\
\hline \multirow[t]{3}{*}{ Club Index } & 704.5377 & 626.828 & 329.4917 & 118.4837 \\
\hline & $(30.91)$ & $(34.57)$ & $(41.45)$ & $(39.15)$ \\
\hline & [489.3152] & {$[185.9556]$} & [272.4137] & [107.6798] \\
\hline \multirow[t]{3}{*}{ Water Index } & 26.7796 & 52.1477 & 22.6919 & 9.9328 \\
\hline & $(1.95)$ & $(4.77)$ & $(4.73)$ & $(5.44)$ \\
\hline & [71.4119] & [27.3803] & [29.3193] & [8.8409] \\
\hline \multirow[t]{3}{*}{ Land Index } & -20.6632 & -27.3879 & -10.1226 & -1.9362 \\
\hline & $(1.70)$ & $(2.83)$ & $(2.39)$ & $(1.20)$ \\
\hline & [1.5910] & [2.0075] & {$[-4.8534]$} & {$[-0.8321]$} \\
\hline \multirow[t]{3}{*}{ Amusement Index } & -43.7147 & -89.7056 & -35.5775 & -0.0716 \\
\hline & $(1.82)$ & $(4.70)$ & $(4.25)$ & $(0.02)$ \\
\hline & {$[-7.8754]$} & [31.0430] & {$[-29.9084]$} & {$[-2.1386]$} \\
\hline \multirow{3}{*}{ Tourism Index } & 99.029 & 65.3695 & 26.8167 & 1.8802 \\
\hline & $(6.96)$ & $(5.78)$ & $(5.41)$ & $(1.00)$ \\
\hline & [77.4947] & [4.2887] & [27.9971] & [4.1201] \\
\hline \multirow[t]{2}{*}{ Winter Index } & -27.1297 & -24.1284 & -12.6891 & -5.0481 \\
\hline & $(2.26)$ & $(2.52)$ & $(3.03)$ & $(3.16)$ \\
\hline
\end{tabular}




\begin{tabular}{lcccc}
\hline & Age 55-64 & Age 65-74 & Age 75-84 & Age 85+ \\
\hline & {$[-67.1889]$} & {$[-8.4470]$} & {$[-24.9625]$} & {$[-8.6686]$} \\
\hline Adjusted R & 0.7402 & 0.6862 & 0.8116 & 0.8593 \\
OLS Sum of Squared Residuals & $3,454,280,106$ & $2,186,035,270$ & $420,202,544.3$ & $60,898,179$ \\
GWR Sum of Squared Residuals & $2,402,727,095$ & $837,598,053$ & $333,826,548.2$ & $54,668,227$ \\
OLS v. GWR ANOVA F-statistic & 32.9825 & 24.7543 & 33.0507 & 14.5566 \\
\hline The first reported coefficient is the OLS estimate, the second is the t-statistic in parentheses, followed by the \\
median GWR estimate in brackets; ${ }^{\dagger}=$ standardized.
\end{tabular}

TABLE 10

Out-Migration 1995-2000

\begin{tabular}{|c|c|c|c|c|}
\hline \multirow{3}{*}{ Intercept } & Age 55-64 & Age $65-74$ & Age $75-84$ & Age $85+$ \\
\hline & $\begin{array}{c}-381.4405 \\
(3.78)\end{array}$ & $\begin{array}{c}-533.3886 \\
(7.45)\end{array}$ & $\begin{array}{r}-283.953 \\
(5.54)\end{array}$ & $\begin{array}{c}-116.4552 \\
(3.74)\end{array}$ \\
\hline & {$[-556.9247]$} & {$[-653.6064]$} & {$[-213.8547]$} & {$[-43.0179]$} \\
\hline $\begin{array}{l}\% \text { of population over } 25 \text { with at least a } \\
\text { BA }\end{array}$ & $\begin{array}{c}14.5586 \\
(5.48) \\
{[14.7092]}\end{array}$ & $\begin{array}{l}-1.8692 \\
(0.99) \\
{[-3.7371]}\end{array}$ & $\begin{array}{l}-4.7055 \\
(3.49) \\
{[-4.0897]}\end{array}$ & $\begin{array}{l}-3.7904 \\
(4.63) \\
{[-2.7216]}\end{array}$ \\
\hline County Population, 1995 & $\begin{array}{c}0.0084 \\
(134.76) \\
{[0.0090]}\end{array}$ & $\begin{array}{c}0.0054 \\
(121.16) \\
{[0.0061]}\end{array}$ & $\begin{array}{c}0.0026 \\
(83.41) \\
{[0.0034]}\end{array}$ & $\begin{array}{c}0.0012 \\
(61.47) \\
{[0.0016]}\end{array}$ \\
\hline $\begin{array}{l}\text { Percent of the population not classified } \\
\text { as white }\end{array}$ & $\begin{array}{l}2.0452 \\
(2.41) \\
{[0.4176]}\end{array}$ & $\begin{array}{l}1.3898 \\
(2.31) \\
{[0.4888]}\end{array}$ & $\begin{array}{l}0.9639 \\
(2.24) \\
{[0.8874]}\end{array}$ & $\begin{array}{l}0.9198 \\
(3.52) \\
{[0.5837]}\end{array}$ \\
\hline Median housing value, owner occupied & $\begin{array}{c}0.0055 \\
(11.32) \\
{[0.0047]}\end{array}$ & $\begin{array}{c}0.0045 \\
(12.93) \\
{[0.0054]}\end{array}$ & $\begin{array}{l}0.0018 \\
(7.39) \\
{[0.0020]}\end{array}$ & $\begin{array}{l}0.001 \\
(6.52) \\
{[0.0004]}\end{array}$ \\
\hline$\%$ of population over 65 & $\begin{array}{c}15.3604 \\
(5.07) \\
{[10.6925]}\end{array}$ & $\begin{array}{l}27.5957 \\
(12.85) \\
{[20.1226]}\end{array}$ & $\begin{array}{l}28.5117 \\
(18.53) \\
{[14.4551]}\end{array}$ & $\begin{array}{l}15.6823 \\
(16.77) \\
{[8.0692]}\end{array}$ \\
\hline \# crimes per 1,000 individuals & $\begin{array}{l}0.9628 \\
(1.61) \\
{[0.7311]}\end{array}$ & $\begin{array}{l}0.0874 \\
(0.21) \\
{[0.0167]}\end{array}$ & $\begin{array}{l}0.9052 \\
(2.98) \\
{[0.3813]}\end{array}$ & $\begin{array}{l}0.7091 \\
(3.84) \\
{[0.2513]}\end{array}$ \\
\hline \# physicians (active non-fed) per $100 \mathrm{~K}$ & $\begin{array}{l}0.1640 \\
(1.20) \\
{[-0.0120]}\end{array}$ & $\begin{array}{l}0.2440 \\
(2.52) \\
{[0.1721]}\end{array}$ & $\begin{array}{l}0.3220 \\
(4.65) \\
{[0.3692]}\end{array}$ & $\begin{array}{l}0.3060 \\
(7.27) \\
{[0.3847]}\end{array}$ \\
\hline$\%$ civilians employed in health services & $\begin{array}{c}-16.7057 \\
(3.49) \\
{[-14.5743]}\end{array}$ & $\begin{array}{c}-10.9591 \\
(3.24) \\
{[-9.1173]}\end{array}$ & $\begin{array}{l}-8.1906 \\
(3.38) \\
{[-7.8106]}\end{array}$ & $\begin{array}{l}-3.9753 \\
(2.70) \\
{[-5.3379]}\end{array}$ \\
\hline $\begin{array}{l}\text { ERS Metro/Nonmetro status, Beale code } \\
\text { (1993) }\end{array}$ & $\begin{array}{l}-10.0076 \\
(1.81) \\
{[7.8220]}\end{array}$ & $\begin{array}{l}-7.64 \\
(1.95) \\
{[9.0724]}\end{array}$ & $\begin{array}{c}-19.2203 \\
(6.86) \\
{[-3.2995]}\end{array}$ & $\begin{array}{c}-12.5325 \\
(7.36) \\
{[-5.5561]}\end{array}$ \\
\hline $\begin{array}{l}\text { Property tax level as \% of tax revenues } \\
\quad(1986-87)\end{array}$ & $\begin{array}{l}0.1930 \\
(0.27)\end{array}$ & $\begin{array}{l}0.1772 \\
(0.35)\end{array}$ & $\begin{array}{l}-0.6188 \\
(1.71)\end{array}$ & $\begin{array}{l}-0.664 \\
(3.02)\end{array}$ \\
\hline
\end{tabular}




\begin{tabular}{|c|c|c|c|c|}
\hline & Age 55-64 & Age 65-74 & Age $75-84$ & Age $85+$ \\
\hline & {$[1.0290]$} & {$[0.8677]$} & {$[0.1245]$} & {$[-0.0161]$} \\
\hline \multirow{3}{*}{$\begin{array}{l}\text { County general expenditures (1986-87) } \\
\text { per } 1,000 \text { individuals }\end{array}$} & 0.4834 & 0.5994 & 0.5444 & 0.3385 \\
\hline & (2.59) & $(4.53)$ & $(5.74)$ & $(5.87)$ \\
\hline & {$[0.4495]$} & {$[0.2458]$} & {$[0.1030]$} & [0.0896] \\
\hline \multirow{3}{*}{$\begin{array}{l}\text { \# jobs in eating and drinking } \\
\text { establishments per capita }\end{array}$} & -2.8004 & -0.9559 & -0.4817 & -0.4423 \\
\hline & $(4.92)$ & $(2.37)$ & (1.67) & $(2.52)$ \\
\hline & {$[-1.9089]$} & {$[0.0050]$} & {$[0.0332]$} & {$[-0.0265]$} \\
\hline \multirow{3}{*}{$\begin{array}{l}\text { \# jobs employed in retail sector per } \\
\text { capita }\end{array}$} & -0.6810 & -0.2010 & -0.0266 & -0.1304 \\
\hline & $(0.99)$ & $(0.41)$ & $(0.08)$ & $(0.62)$ \\
\hline & {$[-0.4814]$} & {$[-0.1358]$} & {$[-0.1164]$} & {$[-0.1629]$} \\
\hline \multirow[t]{3}{*}{ Unemployment rate, civilian (1991) } & 0.1872 & 3.1296 & 4.4916 & 2.8445 \\
\hline & $(0.05)$ & $(1.25)$ & $(2.51)$ & (2.61) \\
\hline & [4.4408] & [3.9471] & {$[0.8856]$} & {$[0.5410]$} \\
\hline \multirow[t]{3}{*}{ Average temperature $\dagger$} & -20.4427 & 24.7535 & 23.6393 & 2.3469 \\
\hline & $(1.15)$ & $(1.97)$ & $(2.62)$ & $(0.43)$ \\
\hline & {$[-33.7998]$} & {$[-5.1186]$} & {$[-13.3014]$} & {$[-3.0556]$} \\
\hline \multirow[t]{3}{*}{ Average annual snowfall $\dagger$} & -45.9036 & 6.2309 & 2.7855 & 4.849 \\
\hline & $(2.62)$ & $(0.50)$ & $(0.31)$ & $(0.90)$ \\
\hline & {$[-85.4202]$} & {$[-24.9182]$} & {$[-6.8778]$} & {$[-3.7561]$} \\
\hline \multirow{3}{*}{$\begin{array}{l}\text { Proportion of county land area classified } \\
\text { in water acreage } \dagger\end{array}$} & -47.8954 & -35.9498 & -13.9701 & -4.4501 \\
\hline & $(3.86)$ & (4.09) & $(2.22)$ & $(1.16)$ \\
\hline & {$[-46.0356]$} & {$[-20.1614]$} & {$[-5.5027]$} & {$[-1.9622]$} \\
\hline \multirow{3}{*}{$\begin{array}{l}\text { Proportion of county land area classified } \\
\text { in mountainous acreage } \dagger\end{array}$} & -33.5384 & -23.8425 & -3.8462 & -3.1426 \\
\hline & $(2.65)$ & (2.66) & $(0.60)$ & $(0.80)$ \\
\hline & {$[-31.8530]$} & {$[-18.6096]$} & {$[-7.2530]$} & {$[-6.5355]$} \\
\hline \multirow{3}{*}{$\begin{array}{l}\text { Proportion of county land area classified } \\
\text { in forested acreage } \dagger\end{array}$} & -179.2227 & -150.4764 & -97.3503 & -53.6012 \\
\hline & (8.92) & $(10.58)$ & $(9.55)$ & $(8.65)$ \\
\hline & {$[-178.9382]$} & {$[-84.4317]$} & {$[-32.6396]$} & {$[-23.1975]$} \\
\hline \multirow{3}{*}{$\begin{array}{l}\text { Proportion of county land area classified } \\
\text { in cropland, pasture, and range } \\
\text { acreage } \dagger\end{array}$} & -205.8527 & -171.7545 & -112.1194 & -61.1815 \\
\hline & $(9.47)$ & $(11.16)$ & $(10.17)$ & $(9.13)$ \\
\hline & {$[-202.1427]$} & {$[-91.9615]$} & {$[-54.3216]$} & {$[-33.8325]$} \\
\hline \multirow{3}{*}{$\begin{array}{l}\text { Proportion of county land area classified } \\
\text { in wetland acreage } \dagger\end{array}$} & -24.3025 & -7.6604 & -4.968 & -6.7094 \\
\hline & $(2.02)$ & $(0.90)$ & $(0.81)$ & $(1.81)$ \\
\hline & {$[-7.0661]$} & {$[-0.3041]$} & {$[-3.7970]$} & {$[-4.4769]$} \\
\hline \multirow{3}{*}{$\begin{array}{l}\text { Proportion of county land area classified } \\
\text { in federal, non-federal wildlife } \\
\text { acreage } \dagger\end{array}$} & 2.905 & 9.1258 & 13.9611 & 8.2802 \\
\hline & $(0.27)$ & $(1.21)$ & (2.59) & $(2.53)$ \\
\hline & {$[-2.6758]$} & [2.1243] & [4.2647] & {$[-1.8424]$} \\
\hline \multirow[t]{3}{*}{ Nature index } & -52.4069 & -36.4315 & -15.0436 & -16.8969 \\
\hline & $(7.41)$ & $(7.27)$ & $(4.19)$ & $(7.74)$ \\
\hline & {$[-31.3843]$} & {$[-11.0630]$} & {$[-2.1217]$} & {$[-4.5111]$} \\
\hline \multirow[t]{3}{*}{ Club Index } & 114.4798 & 61.6019 & 72.5919 & 30.8934 \\
\hline & $(10.20)$ & $(7.75)$ & $(12.75)$ & $(8.93)$ \\
\hline & [108.3759] & [15.8556] & {$[-30.2633]$} & {$[-21.5996]$} \\
\hline Water Index & 19.8887 & 38.027 & 21.6659 & 7.1583 \\
\hline
\end{tabular}




\begin{tabular}{lcccc}
\hline & Age 55-64 & Age 65-74 & Age 75-84 & Age 85+ \\
\hline & $(2.94)$ & $(7.94)$ & $(6.31)$ & $(3.43)$ \\
& {$[15.4448]$} & {$[20.3333]$} & {$[6.9160]$} & {$[-0.7525]$} \\
\hline Land Index & -1.1924 & -9.9609 & -8.1194 & -2.3411 \\
& $(0.20)$ & $(2.35)$ & $(2.67)$ & $(1.27)$ \\
Amusement Index & {$[-1.8375]$} & {$[-5.3240]$} & {$[-3.7239]$} & {$[-1.4270]$} \\
& -28.9565 & -55.5618 & -41.3022 & -23.4103 \\
& $(2.45)$ & $(6.64)$ & $(6.89)$ & $(6.42)$ \\
Tourism Index & {$[-56.5444]$} & {$[-49.5172]$} & {$[-16.9021]$} & {$[-13.6237]$} \\
& 16.1741 & 0.3572 & 10.7393 & 9.9094 \\
Winter Index & $(2.31)$ & $(0.07)$ & $(3.02)$ & $(4.59)$ \\
& {$[32.2753]$} & {$[12.1654]$} & {$[5.2784]$} & {$[6.9329]$} \\
& -7.5323 & -3.0844 & -5.7583 & -2.8235 \\
Adjusted R squared & $(1.27)$ & $(0.74)$ & $(1.92)$ & $(1.55)$ \\
OLS Sum of Squared Residuals & {$[-24.9782]$} & {$[-1.2457]$} & {$[4.4898]$} & {$[6.9090]$} \\
GWR Sum of Squared Residuals & 0.9613 & 0.9501 & 0.9175 & 0.8615 \\
OLS v. GWR ANOVA F-statistic & $836,846,835.8$ & $419,931,738.7$ & $215,529,276$ & $79,598,419$ \\
The first reported coefficient is the OLS estimate, the second is the t-statistic in parentheses, followed by the & $716,785,604$ & $302,753,636.1$ & $88,025,888$ & $31,314,751$ \\
median GWR estimate in brackets. $\dagger=$ Standardized. & 21.3955 & \multicolumn{4}{c}{} \\
\hline
\end{tabular}


The Review of Regional Studies, Vol. 37, No. 3, 2007, pp. 303 - 343

TABLE 11

Monte Carlo Stationarity Results for In-Migration

\begin{tabular}{|c|c|c|c|c|}
\hline & Age 55-64 & Age $65-74$ & Age $75-84$ & Age $85+$ \\
\hline Intercept & $0.00^{* * *}$ & $0.00^{* * *}$ & $0.00^{* * *}$ & $0.00^{* * *}$ \\
\hline$\%$ of population over 25 with at least a BA & $0.00^{* * *}$ & $0.45^{\mathrm{n} / \mathrm{s}}$ & $0.00^{* * *}$ & $0.00^{* * *}$ \\
\hline County Population, 1995 & $0.42^{\mathrm{n} / \mathrm{s}}$ & $0.31^{\mathrm{n} / \mathrm{s}}$ & $0.19^{\mathrm{n} / \mathrm{s}}$ & $0.20^{\mathrm{n} / \mathrm{s}}$ \\
\hline$\%$ of population not classified as white & $0.00^{* * *}$ & $0.03^{*}$ & $0.00^{* * *}$ & $0.00^{* * *}$ \\
\hline Median housing value, owner occupied & $0.01^{* *}$ & $0.04^{*}$ & $0.03^{*}$ & $0.51^{\mathrm{n} / \mathrm{s}}$ \\
\hline$\%$ of population over 65 & $0.00^{* * *}$ & $0.06^{\mathrm{n} / \mathrm{s}}$ & $0.00^{* * *}$ & $0.00^{* * *}$ \\
\hline \# crimes per 1,000 individuals & $0.05^{*}$ & $0.89^{\mathrm{n} / \mathrm{s}}$ & $0.58^{\mathrm{n} / \mathrm{s}}$ & $0.49^{\mathrm{n} / \mathrm{s}}$ \\
\hline \# physicians (active non-fed) per $100 \mathrm{~K}$ & $0.27^{\mathrm{n} / \mathrm{s}}$ & $0.70^{\mathrm{n} / \mathrm{s}}$ & $0.29^{\mathrm{n} / \mathrm{s}}$ & $0.63^{\mathrm{n} / \mathrm{s}}$ \\
\hline$\%$ of civilians empl. in health services & $0.10^{\mathrm{n} / \mathrm{s}}$ & $0.43^{\mathrm{n} / \mathrm{s}}$ & $0.55^{\mathrm{n} / \mathrm{s}}$ & $0.56^{\mathrm{n} / \mathrm{s}}$ \\
\hline $\begin{array}{l}\text { ERS Metro/Nonmetro status, Beale code } \\
\text { (1993) }\end{array}$ & $0.16^{\mathrm{n} / \mathrm{s}}$ & $0.67^{\mathrm{n} / \mathrm{s}}$ & $0.07^{\mathrm{n} / \mathrm{s}}$ & $0.14^{\mathrm{n} / \mathrm{s}}$ \\
\hline $\begin{array}{l}\text { Property tax level as \% of tax revenues } \\
\quad(1986-87)\end{array}$ & $0.13^{\mathrm{n} / \mathrm{s}}$ & $0.42^{\mathrm{n} / \mathrm{s}}$ & $0.33^{\mathrm{n} / \mathrm{s}}$ & $0.58^{\mathrm{n} / \mathrm{s}}$ \\
\hline $\begin{array}{l}\text { County general expenditures (1986-87) per } \\
1,000 \text { individuals }\end{array}$ & $0.01^{* *}$ & $0.20^{\mathrm{n} / \mathrm{s}}$ & $0.09^{\mathrm{n} / \mathrm{s}}$ & $0.11^{\mathrm{n} / \mathrm{s}}$ \\
\hline $\begin{array}{l}\text { \# jobs in eating and drinking establishments } \\
\text { per capita }\end{array}$ & $0.72^{\mathrm{n} / \mathrm{s}}$ & $0.76^{\mathrm{n} / \mathrm{s}}$ & $0.12^{\mathrm{n} / \mathrm{s}}$ & $0.08^{\mathrm{n} / \mathrm{s}}$ \\
\hline \# jobs employed in retail sector per capita & $0.08^{\mathrm{n} / \mathrm{s}}$ & $0.26^{\mathrm{n} / \mathrm{s}}$ & $0.12^{\mathrm{n} / \mathrm{s}}$ & $0.03^{*}$ \\
\hline Unemployment rate, civilian (1991) & $0.00^{* * *}$ & $0.04^{*}$ & $0.00^{* * *}$ & $0.00^{* * *}$ \\
\hline Average temperature ${ }^{\dagger}$ & $0.00^{* * *}$ & $0.00^{* * *}$ & $0.00^{* * *}$ & $0.03^{*}$ \\
\hline Average annual snowfall ${ }^{\dagger}$ & $0.68^{\mathrm{n} / \mathrm{s}}$ & $0.62^{\mathrm{n} / \mathrm{s}}$ & $0.42^{\mathrm{n} / \mathrm{s}}$ & $0.00^{* * *}$ \\
\hline Land area classified in water acreage $^{\dagger}$ & $0.15^{\mathrm{n} / \mathrm{s}}$ & $0.47^{\mathrm{n} / \mathrm{s}}$ & $0.20^{\mathrm{n} / \mathrm{s}}$ & $0.03^{*}$ \\
\hline Land area classified in mountainous acreage ${ }^{\dagger}$ & $0.07^{\mathrm{n} / \mathrm{s}}$ & $0.00^{* * *}$ & $0.00^{* * *}$ & $0.47^{\mathrm{n} / \mathrm{s}}$ \\
\hline Land area classified in forested acreage ${ }^{\dagger}$ & $0.09^{\mathrm{n} / \mathrm{s}}$ & $0.38^{\mathrm{n} / \mathrm{s}}$ & $0.16^{\mathrm{n} / \mathrm{s}}$ & $0.12^{\mathrm{n} / \mathrm{s}}$ \\
\hline $\begin{array}{l}\text { Land area classified in cropland, pasture, and } \\
\text { range acreage }{ }^{\dagger}\end{array}$ & $0.06^{\mathrm{n} / \mathrm{s}}$ & $0.13^{\mathrm{n} / \mathrm{s}}$ & $0.09^{\mathrm{n} / \mathrm{s}}$ & $0.15^{\mathrm{n} / \mathrm{s}}$ \\
\hline Land area classified in wetland acreage $\mathrm{e}^{\dagger}$ & $0.02^{*}$ & $0.32^{\mathrm{n} / \mathrm{s}}$ & $0.11^{\mathrm{n} / \mathrm{s}}$ & $0.27^{\mathrm{n} / \mathrm{s}}$ \\
\hline $\begin{array}{l}\text { Land area classified in federal, non-federal } \\
\text { wildlife acreage }^{\dagger}\end{array}$ & $0.03^{*}$ & $0.81^{\mathrm{n} / \mathrm{s}}$ & $0.13^{\mathrm{n} / \mathrm{s}}$ & $0.12^{\mathrm{n} / \mathrm{s}}$ \\
\hline Nature index & $0.03^{*}$ & $0.80^{\mathrm{n} / \mathrm{s}}$ & $0.04^{*}$ & $0.59^{\mathrm{n} / \mathrm{s}}$ \\
\hline Club Index & $0.00^{* * *}$ & $0.07^{\mathrm{n} / \mathrm{s}}$ & $0.00^{* * *}$ & $0.00^{* * *}$ \\
\hline Water Index & $0.21^{\mathrm{n} / \mathrm{s}}$ & $0.95^{\mathrm{n} / \mathrm{s}}$ & $0.04^{*}$ & $0.13^{\mathrm{n} / \mathrm{s}}$ \\
\hline Land Index & $0.77^{\mathrm{n} / \mathrm{s}}$ & $0.04^{*}$ & $0.24^{\mathrm{n} / \mathrm{s}}$ & $0.06^{\mathrm{n} / \mathrm{s}}$ \\
\hline Amusement Places Index & $0.22^{\mathrm{n} / \mathrm{s}}$ & $0.95^{\mathrm{n} / \mathrm{s}}$ & $0.25^{\mathrm{n} / \mathrm{s}}$ & $0.24^{\mathrm{n} / \mathrm{s}}$ \\
\hline Tourism Index & $0.68^{\mathrm{n} / \mathrm{s}}$ & $0.99^{\mathrm{n} / \mathrm{s}}$ & $0.85^{\mathrm{n} / \mathrm{s}}$ & $0.80^{\mathrm{n} / \mathrm{s}}$ \\
\hline Winter Index & $0.00^{* * *}$ & $0.35^{\mathrm{n} / \mathrm{s}}$ & $0.00^{* * *}$ & $0.10^{\mathrm{n} / \mathrm{s}}$ \\
\hline
\end{tabular}


Jensen/Deller: Spatial Modeling of the Migration of Older People

TABLE 12

Monte Carlo Stationarity Results for In-Migration

\begin{tabular}{|c|c|c|c|c|}
\hline & Age 55-64 & Age 65-74 & Age $75-84$ & Age $85+$ \\
\hline Intercept & $0.03^{*}$ & $0.00^{* * *}$ & $0.00^{* * *}$ & $0.00^{* * *}$ \\
\hline$\%$ of population over 25 with at least a BA & $0.02^{*}$ & $0.44^{\mathrm{n} / \mathrm{s}}$ & $0.41^{\mathrm{n} / \mathrm{s}}$ & $0.22^{\mathrm{n} / \mathrm{s}}$ \\
\hline County Population, 1995 & $0.12^{\mathrm{n} / \mathrm{s}}$ & $0.03^{*}$ & $0.00^{* * *}$ & $0.00^{* * *}$ \\
\hline$\%$ of population not classified as white & $0.00^{* * *}$ & $0.00^{* * *}$ & $0.00^{* * *}$ & $0.00^{* * *}$ \\
\hline Median housing value, owner occupied & $0.36^{\mathrm{n} / \mathrm{s}}$ & $0.03^{*}$ & $0.61^{\mathrm{n} / \mathrm{s}}$ & $0.67^{\mathrm{n} / \mathrm{s}}$ \\
\hline$\%$ of population over 65 & $0.00^{* * *}$ & $0.00^{* * *}$ & $0.00^{* * *}$ & $0.01^{* *}$ \\
\hline \# crimes per 1,000 individuals & $0.88^{\mathrm{n} / \mathrm{s}}$ & $0.54^{\mathrm{n} / \mathrm{s}}$ & $0.11^{\mathrm{n} / \mathrm{s}}$ & $0.20^{\mathrm{n} / \mathrm{s}}$ \\
\hline \# physicians (active non-fed) per 100K & $0.10^{\mathrm{n} / \mathrm{s}}$ & $0.37^{\mathrm{n} / \mathrm{s}}$ & $0.17^{\mathrm{n} / \mathrm{s}}$ & $0.05^{*}$ \\
\hline$\%$ of civilians empl. in health services & $0.12^{\mathrm{n} / \mathrm{s}}$ & $0.12^{\mathrm{n} / \mathrm{s}}$ & $0.18^{\mathrm{n} / \mathrm{s}}$ & $0.78^{\mathrm{n} / \mathrm{s}}$ \\
\hline $\begin{array}{l}\text { ERS Metro/Nonmetro status, Beale code } \\
\text { (1993) }\end{array}$ & $0.00^{* * *}$ & $0.00^{* * *}$ & $0.78^{\mathrm{n} / \mathrm{s}}$ & $0.95^{\mathrm{n} / \mathrm{s}}$ \\
\hline $\begin{array}{l}\text { Property tax level as \% of tax revenues } \\
\quad(1986-87)\end{array}$ & $0.29^{\mathrm{n} / \mathrm{s}}$ & $0.21^{\mathrm{n} / \mathrm{s}}$ & $0.54^{\mathrm{n} / \mathrm{s}}$ & $0.98^{\mathrm{n} / \mathrm{s}}$ \\
\hline $\begin{array}{l}\text { County general expenditures (1986-87) per } \\
1,000 \text { individuals }\end{array}$ & $0.02^{*}$ & $0.08^{\mathrm{n} / \mathrm{s}}$ & $0.84^{\mathrm{n} / \mathrm{s}}$ & $0.70^{\mathrm{n} / \mathrm{s}}$ \\
\hline $\begin{array}{l}\text { \# jobs in eating and drinking establishments } \\
\text { per capita }\end{array}$ & $0.37^{\mathrm{n} / \mathrm{s}}$ & $0.77^{\mathrm{n} / \mathrm{s}}$ & $0.98^{\mathrm{n} / \mathrm{s}}$ & $0.94^{\mathrm{n} / \mathrm{s}}$ \\
\hline \# jobs employed in retail sector per capita & $0.99^{\mathrm{n} / \mathrm{s}}$ & $0.89^{\mathrm{n} / \mathrm{s}}$ & $0.33^{\mathrm{n} / \mathrm{s}}$ & $0.73^{\mathrm{n} / \mathrm{s}}$ \\
\hline Unemployment rate, civilian (1991) & $0.00^{* * *}$ & $0.00^{* * *}$ & $0.05^{*}$ & $0.49^{\mathrm{n} / \mathrm{s}}$ \\
\hline Average temperature ${ }^{\dagger}$ & $0.54^{\mathrm{n} / \mathrm{s}}$ & $0.00^{* * *}$ & $0.00^{* * *}$ & $0.00^{* * *}$ \\
\hline Average annual snowfall ${ }^{\dagger}$ & $0.00^{* * *}$ & $0.25^{\mathrm{n} / \mathrm{s}}$ & $0.82^{\mathrm{n} / \mathrm{s}}$ & $0.85^{\mathrm{n} / \mathrm{s}}$ \\
\hline Land area classified in water acreage $^{\dagger}$ & $0.00^{* * *}$ & $0.01^{* *}$ & $0.29^{\mathrm{n} / \mathrm{s}}$ & $0.72^{\mathrm{n} / \mathrm{s}}$ \\
\hline Land area classified in mountainous acreage $e^{\dagger}$ & $0.27^{\mathrm{n} / \mathrm{s}}$ & $0.07^{\mathrm{n} / \mathrm{s}}$ & $0.00^{* * *}$ & $0.00^{* * *}$ \\
\hline Land area classified in forested acreage ${ }^{\dagger}$ & $0.04^{*}$ & $0.01^{* *}$ & $0.02^{*}$ & $0.03^{*}$ \\
\hline $\begin{array}{l}\text { Land area classified in cropland, pasture, and } \\
\text { range acreage } \mathrm{e}^{\dagger}\end{array}$ & $0.15^{\mathrm{n} / \mathrm{s}}$ & $0.13^{\mathrm{n} / \mathrm{s}}$ & $0.03^{*}$ & $0.09^{\mathrm{n} / \mathrm{s}}$ \\
\hline Land area classified in wetland acreage ${ }^{\dagger}$ & $0.00^{* * *}$ & $0.00^{* * *}$ & $0.20^{\mathrm{n} / \mathrm{s}}$ & $0.24^{\mathrm{n} / \mathrm{s}}$ \\
\hline $\begin{array}{l}\text { Land area classified in federal, non-federal } \\
\text { wildlife acreage }\end{array}$ & $0.85^{\mathrm{n} / \mathrm{s}}$ & $0.90^{\mathrm{n} / \mathrm{s}}$ & $0.99^{\mathrm{n} / \mathrm{s}}$ & $0.99^{\mathrm{n} / \mathrm{s}}$ \\
\hline Nature index & $0.32^{\mathrm{n} / \mathrm{s}}$ & $0.69^{\mathrm{n} / \mathrm{s}}$ & $0.36^{\mathrm{n} / \mathrm{s}}$ & $0.94^{\mathrm{n} / \mathrm{s}}$ \\
\hline Club Index & $0.04^{*}$ & $0.17^{\mathrm{n} / \mathrm{s}}$ & $0.00^{* * *}$ & $0.00^{* * *}$ \\
\hline Water Index & $0.36^{\mathrm{n} / \mathrm{s}}$ & $0.42^{\mathrm{n} / \mathrm{s}}$ & $0.94^{\mathrm{n} / \mathrm{s}}$ & $0.65^{\mathrm{n} / \mathrm{s}}$ \\
\hline Land Index & $0.03^{*}$ & $0.68^{\mathrm{n} / \mathrm{s}}$ & $0.96^{\mathrm{n} / \mathrm{s}}$ & $0.70^{\mathrm{n} / \mathrm{s}}$ \\
\hline Amusement Places Index & $0.00^{* * *}$ & $0.02^{*}$ & $0.87^{\mathrm{n} / \mathrm{s}}$ & $0.76^{\mathrm{n} / \mathrm{s}}$ \\
\hline Tourism Index & $0.00^{* * *}$ & $0.32^{\mathrm{n} / \mathrm{s}}$ & $0.89^{\mathrm{n} / \mathrm{s}}$ & $0.39^{\mathrm{n} / \mathrm{s}}$ \\
\hline Winter Index & $0.26^{\mathrm{n} / \mathrm{s}}$ & $0.00^{* * *}$ & $0.01^{* *}$ & $0.00^{* * *}$ \\
\hline
\end{tabular}


overall local government spending may increase the out-flow of older migrants. As expected, the unemployment rate does not influence the migration decisions of older people.

Now we can turn our attention to the amenity variables of interest, first the natural then the built. Areas that have higher than average temperatures will have higher levels of in-migration, though the effect drops substantially for those aged 85+. Higher than average temperature's effect on out-migration was negative, though not significant, for those aged 55-64. For the rest of the age groups, a higher temperature had a positive effect on out-migration, though for ages $85+$ that effect was not significant. Warmer areas seem to attract older migrants all else held constant, but other factors may be of more importance as they age. These warmer areas may also be subject to higher levels of out-migration.

While areas with higher than average snowfall have significantly lower levels of outmigration for the youngest age group, the results for the rest of the age groups are positive but lacking significance. Areas with snowfall in excess of average levels will have significantly lower levels of in-migration of older people at each age grouping. Along with the proportion of mountainous acreage in a county, snowfall was hypothesized to have a positive impact on in-migration for the younger age groups and decrease in significance as other factors became more important determinants of migration. Snowfall may hold some of those aged 55-64 in an area, though it has a deterrent effect on inmigration of older people. For in-migration, an increase in mountainous acreage has a mixed but insignificant effect. For out-migration, an increase in the proportion of mountainous acreage has a negative impact on the movements for the younger two age groups, 55-64 and 64-74, and has little impact on older groups. The same pattern emerges that did for snowfall. While decreasing the levels of out-migration for the younger age groups, snowfall and the proportion of mountainous acreage had a negative or insignificant impact on the levels of in-migration. Migrants appear not to value areas with more mountains or higher levels of snowfall but are not necessarily repelled from areas where these factors are present, at least for younger migrants.

The proportion of water acreage in a county, while hypothesized to have a positive impact on in-migration (due to the allure of lake houses and lake districts) and a negative role in out-migration, does not play out in that way in these results. The amount of water acreage in a county is able to deter out-migration. This is true for all but the oldest, $85+$, age group. For in-migration, however, the amount of water acreage has an increasingly significant negative impact. While counties with higher water acreage are able to deter out-migration at some level, they are also unable to attract new migrants. This is counter to the hypothesized results; perhaps a measure of oceanfront or quality of water such as clarity would have been a more appropriate measure.

Forested acreage is also hypothesized to be a positive amenity as older migrants are drawn to natural areas. This is not the case; the amount of forested acreage has a significant negative impact on increased out-migration for all age groups. The proportion of forested acreage also has a significant negative impact on out-migration. The coefficients 
are nearly equal in magnitude, though for the two oldest groups the dampening effect is slightly larger, indicating that over time the number of older people will increase in the county. The amount of cropland, pasture, and range acreage also has a significant negative impact on out-migration as well as on in-migration. Again, the magnitude of the dampening effect on out-migration is larger than that of in-migration. This would indicate that in areas where the proportion of this type of land is higher, people are reluctant to leave despite the unappealing nature for in-migrants. Wetland acreage has little impact on either in-migrants or out-migrants. Included as a way to complete the land types available to migrants, this appears to have the least impact on migrants' choices.

An increase in the amount of wildlife acreage positively effects out-migration, though only significantly for ages $75-84$ and $85+$. The proportion of wildlife acreage does significantly increase the number of in-migrants at all age groupings, however. Previous work (Duffy-Deno 1998, Lewis, Hunt, and Planting 2002) suggested that large tracts of land set aside for conservation (i.e., wilderness, national/state parks and forests) restrict the amount of land available for economic development. The results here suggest that older migrants are searching out areas that have attributes associated with wildlife.

We can now move on to examine the statistically constructed amenity indexes, starting with the Nature index. This index was created to measure the effect of campgrounds and picnic areas. Higher values of this index are associated with higher levels of inmigration, though significantly only for the first two age groupings. For out-migration, the estimates display the pattern seen with in-migration, though as a deterrent to outmigration; the coefficient is largest for the younger migrants (55-64) and drops down to its lowest value for oldest migrants $(85+)$. The pattern appears that camping and picnic areas may discourage out-migration.

The Clubs index, measuring the impact of golf and tennis opportunities (Table 3), has both a large and positive impact on the migration of older people. Based on the relative size of the coefficients in relation to the other constructed indexes, it is evident that older migrants place high value on the existence of golf and tennis facilities. ${ }^{5}$ For in-migration, the estimates display the step-down pattern that is common to these results. With the importance of these facilities for in-migration, their presence might be thought to discourage out-migration. Across all age groups, the higher levels of the Club index are associated with higher levels of out-migration.

The Water index, weighted heavily by the presence of marinas (Table 4), appears to have a positive impact on the number of older in-migrants and, for the most part, outmigrants. The results for in-migration are positive, with the largest coefficient occurring in the 65-74 age grouping; the 55-64 result is the only estimate that is statistically weak. This, combined with the water acreage result discussed above, is consistent with other studies seeking to understand how amenities influence economic growth. As argued in Green, Deller, and Marcouiller (2005), simply having the "raw" natural amenity is not

\footnotetext{
${ }^{5}$ As each index has been standardized such comparisons are legitimate.
} 
sufficient to attract economic growth and development; rather economic institutions (e.g., businesses such as marinas) need to be in place.

The Land index, which is heavily weighted by trails constructed by the U.S. Army Corps of Engineers, showed mixed results. For in-migration, the estimates indicated that the existence of trails is a deterrent, though the values are statistically weak. The results for out-migration show the presence of trails to deter migrants from leaving. Again, the results are statistically weak. While the results are mixed, they point to high levels of trails being associated with lower levels of in-migration but retention of those older people who remain in the area.

The Tourism index attempts to capture the presence of a range of tourist attractions: museums, historic places, natural resource-based tourist attractions (Table 6). The results for in-migration are fairly clear. Higher levels of these types of attractions draw higher levels in in-migrants from 55-64 to 85+, though the last age group is not significant. For out-migration, the same pattern is present. Higher levels of the tourism index are associated with higher levels of out-migration. Meant to complement the Tourism index by measuring another set of attractions, the Amusement index is composed of the number and density of amusement places as well as miniature golf facilities (Table 7). For inmigration, this index does not seem to affect those 55-64 or 85+ but has a larger negative impact on those 65-74 and 75-84. For out-migration, the pattern is significantly negative for each age group except those 55-64. A deterrent for several sets of in-migrants, the Amusement index does well in reducing out-migration.

The final measure of built amenities, the Winter index, concentrates heavily on the existence of downhill skiing facilities and less on other winter pursuits (e.g., snowmobiling or cross-country skiing). For the estimates, the presence of these facilities has a negative association with increases in both in- and out-migration, though not significantly. The result is consistent with the snowfall variable discussed earlier. This suggests that older migrants are not attracted to areas of heavy snowfall, nor does the addition of built amenities to take advantage of the snow help with attraction of older migrants.

One of the patterns that we consistently find is what we refer to as a "step-down" pattern when looking across the four age classifications. Specifically, the absolute size of the coefficients appears to be consistently larger for migrants age 55-64 and becomes progressively smaller as age increases. We do find many cases where the statistical significance of the coefficients varies significantly across age groupings where variables may be strong predictors of those younger than 75 but become insignificant for those older than 75. This result in itself provides strong evidence that studies that aggregate older migrants into one group are masking important differences. The observed "stepdown" pattern may simply be a by-product of the absolute size of the number of migrants within each age group. In other words, because there is a greater number of migrants in the 55-64 age group than in, say, the $85+$ group, the estimated coefficients will be larger. This pattern warrants further investigation, perhaps redefining how the dependent variable is defined. 
One of the powers of the GWR approach is that it not only allows for spatial variation in the influence of the migration explanatory variables such as amenities but, when matched with GIS mapping software, allows for a visual representation of the spatial coefficients. Based on the Monte Carlo simulations, 92 (38.3 percent) of the 240 coefficients exhibit significant spatial variation. Space prevents us from sharing all 92 mappings of these coefficients. ${ }^{6}$ A sampling of the spatial results is provided in Figures 1a through $2 \mathrm{~d}$ where we map the spatial coefficients for the influence of temperature on inmigration for the four age classifications as well as the results for the Club index.

Consider the impact of temperature on the in-migration of those age 55-64 (Figure 1a). The GWR coefficients range from -14.22 to 389.86 , suggesting that in parts of the upper Great Plains and Great Lakes states, warmer average temperatures may have a negative impact on the migration of older people. This somewhat surprising pattern holds true for all four age groups; within the retirement migration literature, attraction to colder climates seems counterintuitive. Work by Marcouiller et al. (1996) and Deller, Marcouiller, and Green (1997) suggests that retirement migration in the northern states is closely tied to the supply of recreational housing. In short, summer homes are being converted into four-season houses with the intent of retirement. In the case of Michigan, Minnesota, and Wisconsin, many of these retirees are younger, physically active, and revealed a preference for winter activities.

The more predominate result suggests that the majority of older migrants are attracted to areas with warmer climates, and the effects are the strongest in the southeastern U.S. In all four of the age classifications we examine, Florida, parts of Georgia, and the Carolinas seem to benefit from their temperate climates in terms of attracting older migrants. The 65-74 age group, the "traditional" group when thinking about retirement migration, provides the most interesting spatial patterns (Figure 1b). Here the spatial coefficients range from -47.24 to 624.51 , with greater geographic variety. We find evidence that there are pockets in the southern states where higher average temperatures can discourage in-migration, particularly the region where Arkansas, Louisiana, Oklahoma, and Texas come together along with the southern part of Texas on the Mexico border. We also see stronger evidence of the positive effect that temperature has in the northwestern parts of the U.S. We can also see that there are parts of the Appalachians where average temperature can have a stronger impact on in-migration.

Consider the spatial variation in the influence of our Club index on in-migration patterns (Figures 2a through 2d). Recalling that the Club index captures the presence of golf courses and tennis courts, we might expect that areas with a reputation for golf "havens" such as the Pinehurst region of North Carolina or Hilton Head of South Carolina have a critical mass that creates an agglomeration effect. Within a GWR setting this agglomeration effect would be captured through clustering of larger coefficients. What we uncover, however, is that the influence of clubs is the strongest in the western states and the smallest in the northeast. As with the discussion of average temperature above, the most

\footnotetext{
${ }^{6} \mathrm{~A}$ complete set of mappings is available in Jensen (2006).
} 


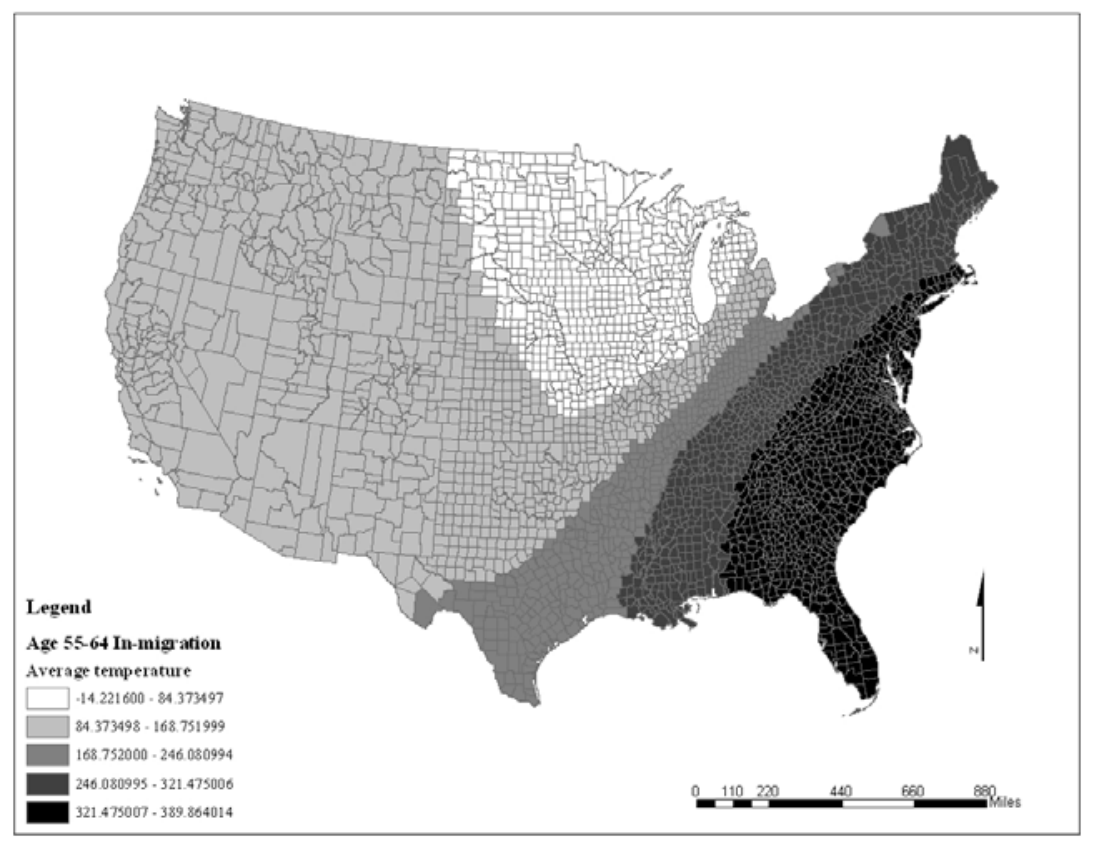

FIGURE 1a. Average Temperature, In-Migration Age 55-64

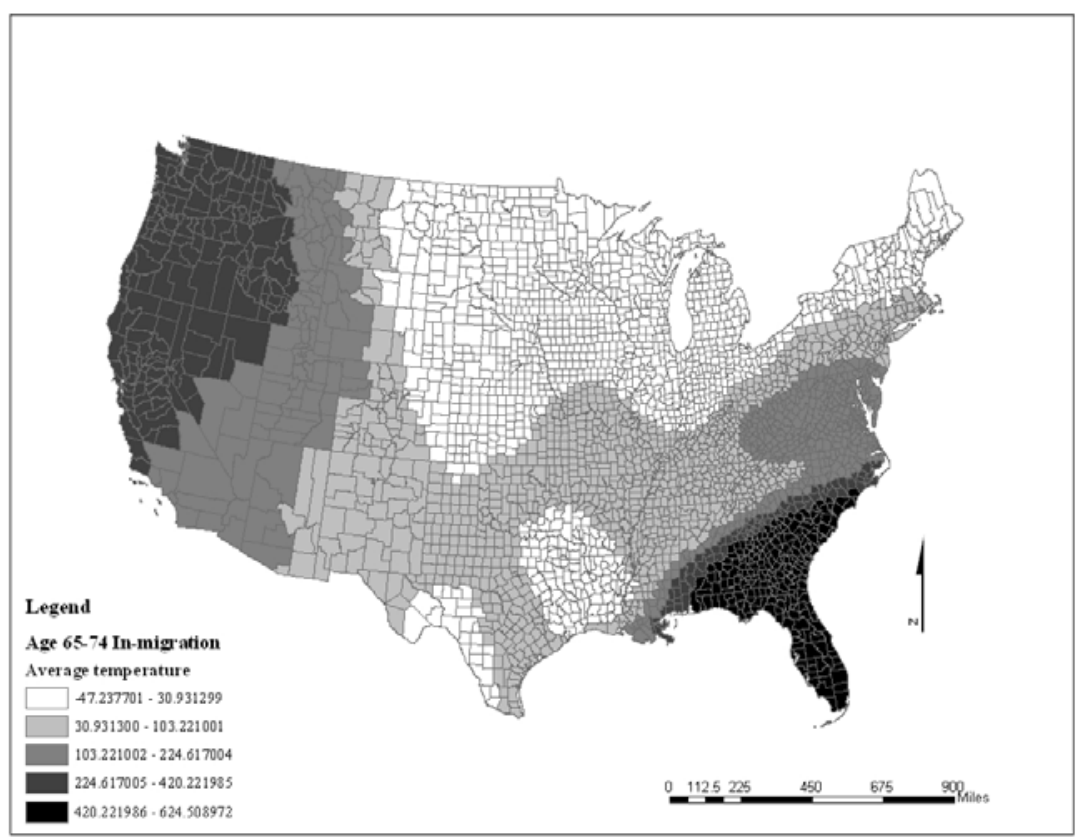

FIGURE 1b. Average Temperature, In-Migration Age 65-74 


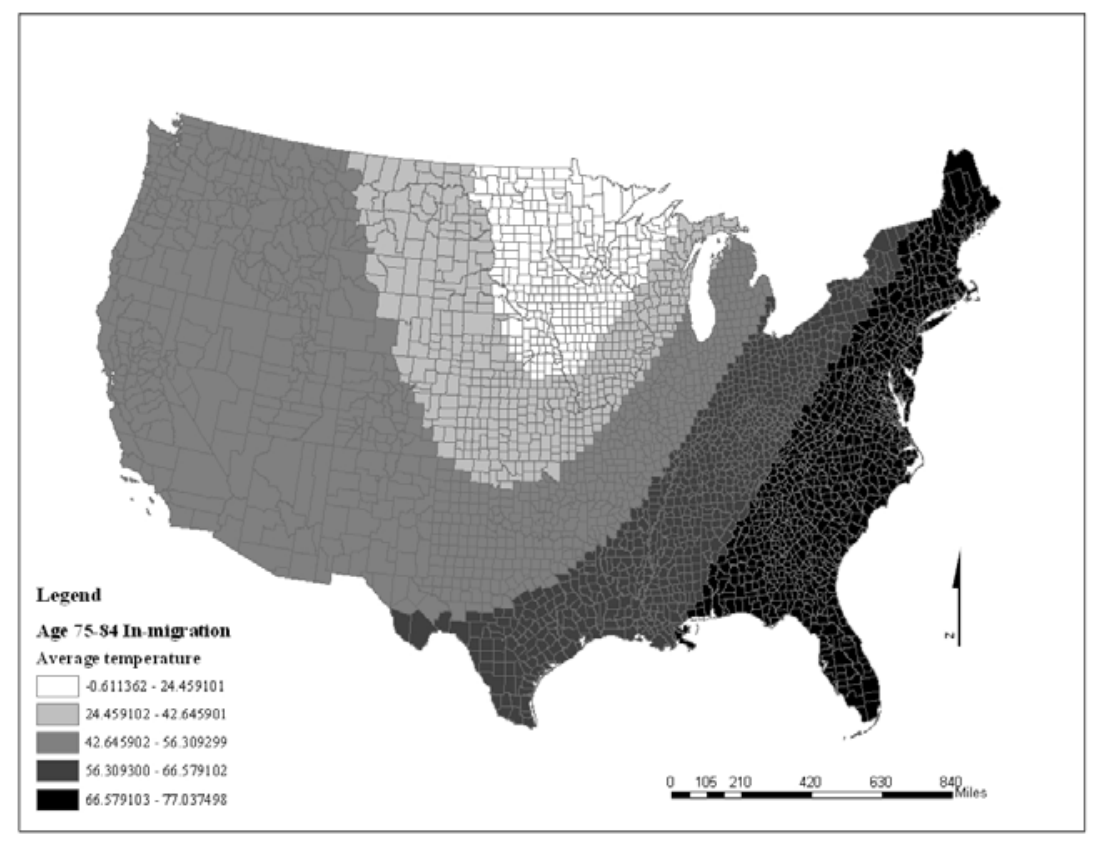

FIGURE 1c. Average Temperature, In-Migration Age 75-84

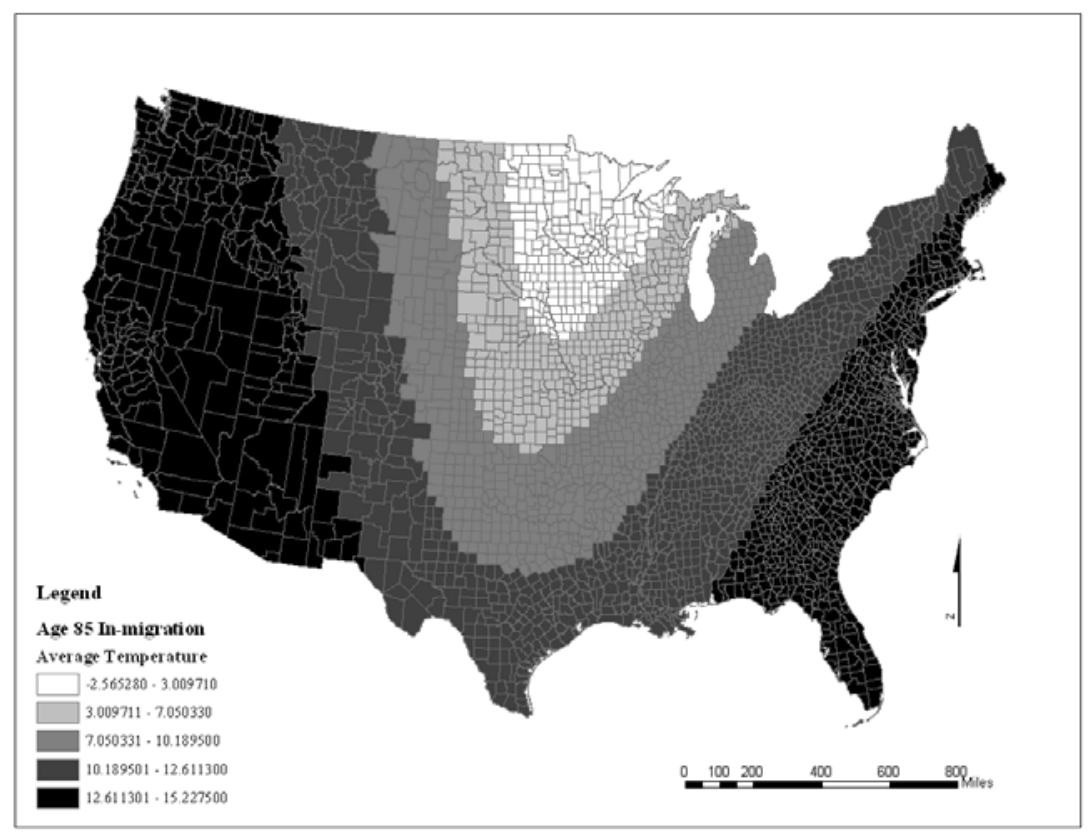

FIGURE 1d. Average Temperature, In-Migration Age 85+ 


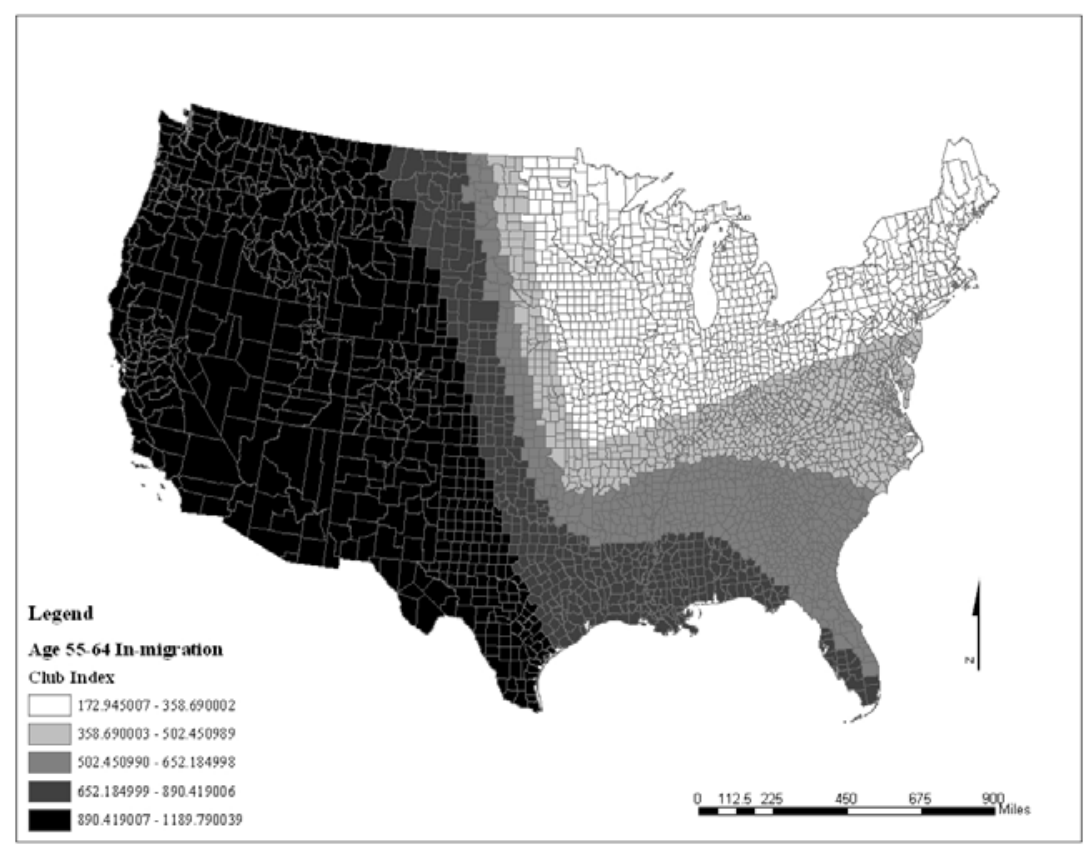

FIGURE 2a. Club Index, In-Migration Age 55-64

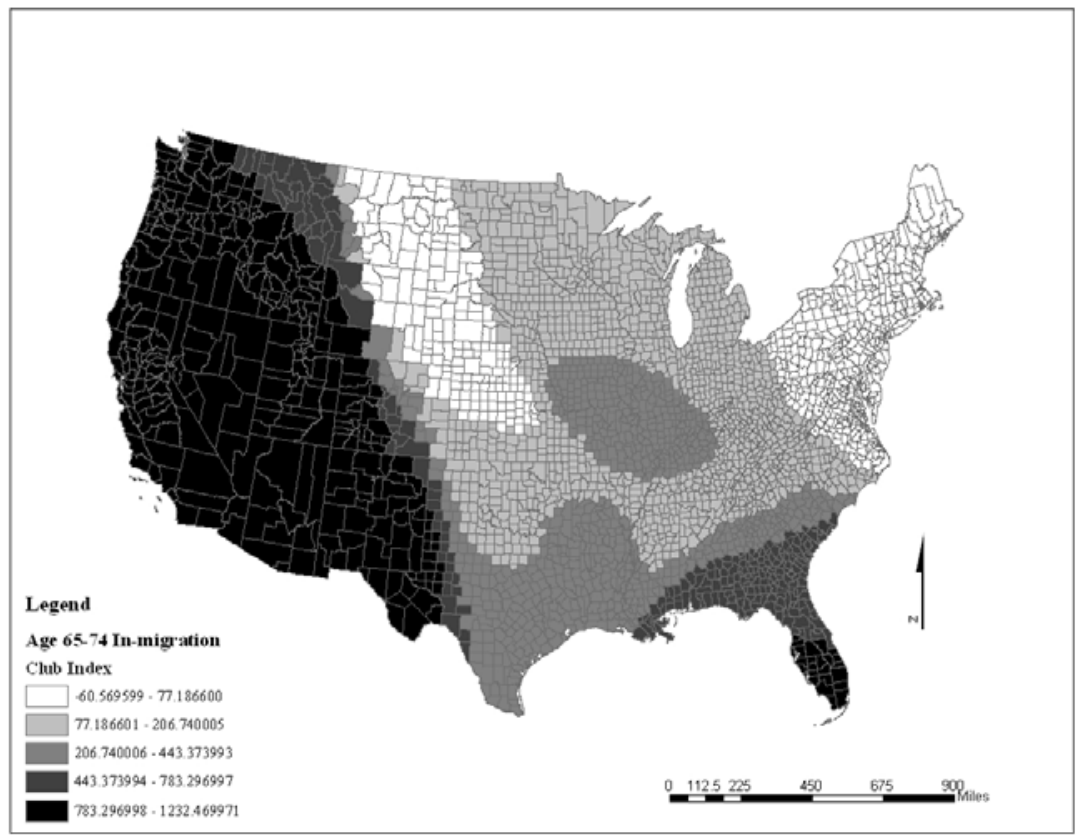

FIGURE 2b. Club Index, In-Migration Age 65-74 


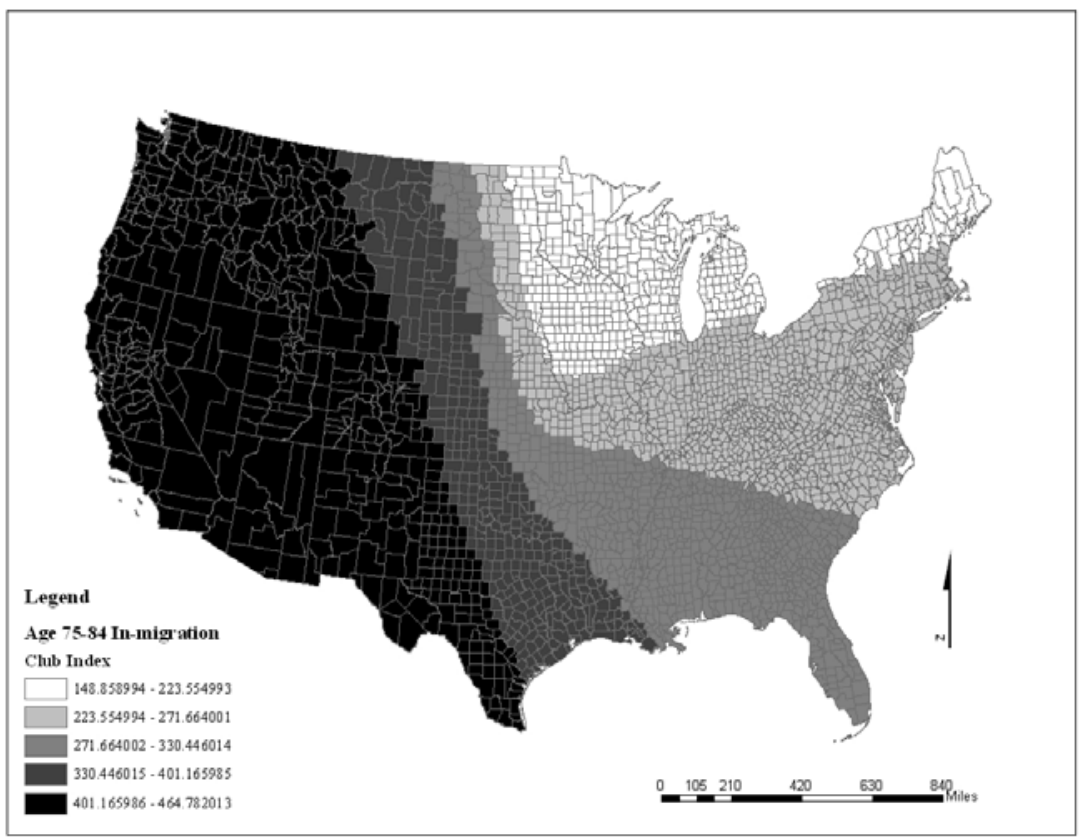

FIGURE 2c. Club Index, In-Migration Age 75-84

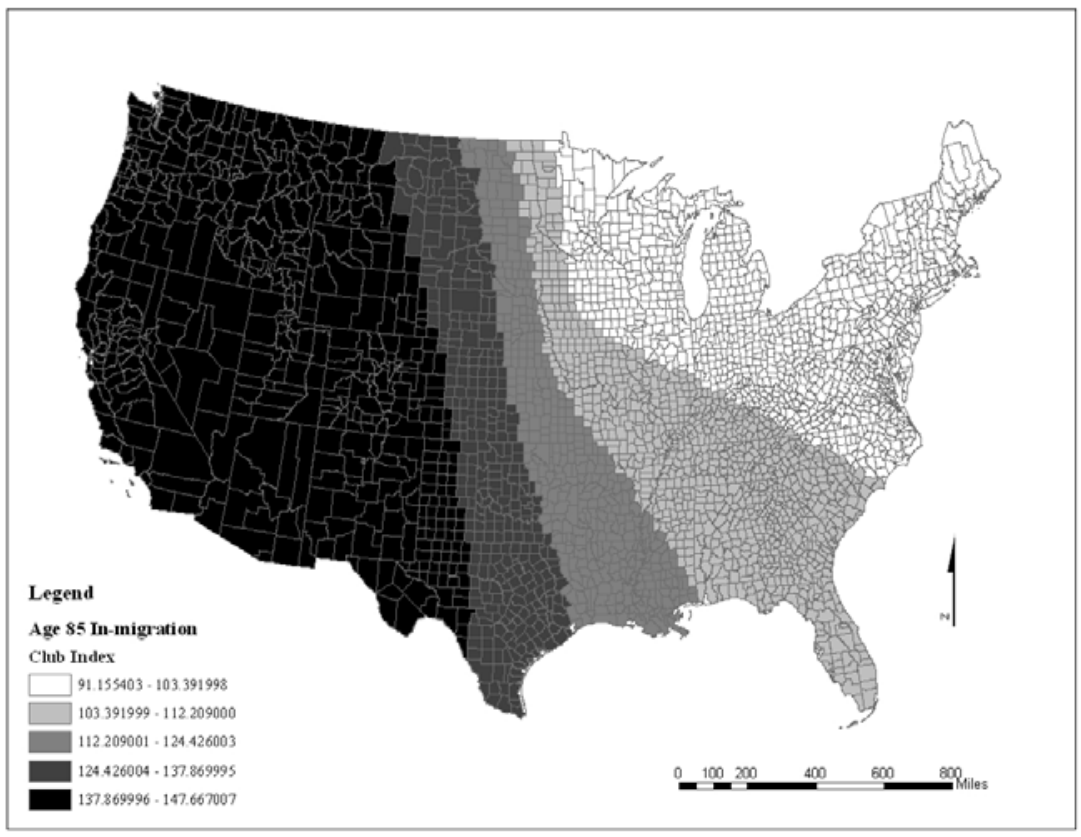

FIGURE 2d. Club Index, In-Migration Age 85+ 
interesting age grouping is 65-74 (Figure 2b). While the same general west-to-east pattern holds with the strongest effect of clubs in the west and the weakest in the northeast, we can see that there are specific pockets of the U.S. where the role of clubs varies. For example, the impact of clubs in the high plains of Montana south through Colorado seems to be quite small; but as soon as we move west into the mountains, the impact of clubs is the highest in the U.S. What this result suggests is that building golf courses in eastern Colorado will have a small impact, whereas building the same golf course in western Colorado has the potential for a much greater impact on the in-migration of older people. We can also see that the presence of clubs has a much stronger impact in southern Florida than, say, the coastal region of Texas. There is also a pocket in the heartland of the U.S. that coincides with the Ozarks. As with the Florida-Texas comparison, this latter result suggests that building a golf course in the Ozarks will have a larger impact on older in-migration than a similar investment in the northern part of Appalachia.

From this simple discussion of our results on spatial variation in the role of average temperature and our Clubs index on the in-migration of older people, it becomes apparent that global parameters derived from traditional regression methods mask important spatial differences. We found that potentially important policy variables, such as built amenities not limited to golf courses and tennis facilities, can have significant spatial variations. These results suggest that what may work in the mountain west may not work in parts of Appalachia. The results also suggest that there can be important variations across age classifications, and care must be taken when speaking of older migrants as a homogenous group; what drives the migration decisions of new retirees is different from what drives the oldest retirees.

\section{CONCLUSIONS}

This study addressed three aspects of the retirement migration literature. First we examined whether older migrants can be treated as a homogenous group. We did this by explicitly modeling older migrants across four age classifications. Second, we looked in detail at the role of amenities, both natural and built, in the migration decisions of older people. Finally, we employed Geographically Weighted Regression methods to test for spatial variation in the role of amenities in the migration patterns of older people. Our results suggest that older migrants can not be treated as a homogenous group, amenities have a predictable role in explaining their migration decisions, and there is significant spatial variation in the affects of a number of migration explanatory variables.

We found evidence of a "step-down" pattern across our four age classifications. The largest impacts were for those aged 55-64, and the smallest were for those aged 85+. Although we did not directly test for coefficient equality across the four age classifications, the consistency of the pattern across almost all of our control variables lends strong support to the hypothesis that older migrants must be treated as a heterogeneous group. This result could be the by-product of the magnitude of absolute flow levels; as the age classification increases, the flow levels of migrants decline. Additional work taking into 
account the flow level concern is required before we can make definitive conclusions about this "step-down" pattern.

Our amenity results were particularly interesting. We found that older migrants tend to be attracted to warmer weather and are not necessarily attracted to areas with lakes and forests, nor are they attracted to areas that could best be described as traditional crop agriculture. Indeed, our natural amenity measures did not perform as expected. Built amenities that are associated with natural amenities, such as camping facilities and hiking trails, marinas and fishing docks, and golf courses have a strong predictive relationship with the migration of older people. Older migrants are not attracted to areas with a large number of amusement attractions such as the Wisconsin Dells or Gatlinburg, Tennessee, but rather are attracted to areas that have more natural, historical, or cultural attractions. Despite the booming winter recreational ski areas such as Big Sky, Montana, older migrants tend not to be attracted to areas that offer winter recreational opportunities. The conclusion is that simply having the natural amenity is not sufficient to promote the inmigration of older people; there must be a built infrastructure supporting or complementing the natural amenities.

Many amenity variables as well as a number of other control variables have the "same sign" problem noted by Conway and Houtenville (2001) but may tell an interesting story nonetheless. Significance in both in- and out-migration but larger coefficients in in-migration could mean that it is more important for in-migration and vice-versa. The "same sign" problem could also be due to the idea that areas of high in-migration are also areas of high out-migration since those who have migrated before tend to be more likely than others to migrate again (Cromartie 2004). This creates a more footloose population in these areas. An extension of this would be to identify those areas of high and low migration, both in and out, to distinguish areas of declining counties as well as growing ones and then go on to identify the factors present in those counties that may contribute to those trends

Finally, and perhaps most importantly, we found strong support for the use of the GWR estimator. In all age groups, the GWR estimator outperformed the OLS estimator based on the ANOVA comparisons of the squared errors. Rather than restricting the estimation to global analysis and having important local variations be averaged into the results, GWR allows those variations to be examined and viewed. The ability of the GWR software to integrate the results of the regressions with ArcView or other mapping software allows the researcher to examine the changing spatial impact of their parameters with what Fotheringham, Brunsdon, and Charlton (2002) refer to as "spatial microscope." The researcher then has the ability to develop hypotheses from the data where previously the data was used to test a priori hypotheses, as is the case with some other forms of spatial econometrics (Fotheringham, Brunsdon, and Charlton 2002). In this research, amenity measures were calculated and their variability was examined and mapped. The spatial nature of the amenity measures, both natural and built, as shown by this analysis, had distinctly different implications for development in individual localities. 
The Review of Regional Studies, Vol. 37, No. 3, 2007, pp. 303 - 343

\section{REFERENCES}

Beale, C.L. and K.M. Johnson, 1998. "The Identification of Recreational Counties in Nonmetropolitan Areas of the USA," Population Research and Policy Review 17(1), 37-53.

Cadwallader, M., 1992. Migration and Residential Mobility: Macro and Micro Approaches. The University of Wisconsin Press: Madison, WI.

Cebula, R.J., 1980. "Voting with One's Feet: A Critique of the Evidence," Regional Science and Urban Economics 10, 91-107.

Charney, A.H., 1993. "Migration and the Public Sector: A Survey," Regional Studies 27(4), 313-326.

Choi, N. 1996. "Older Persons Who Move: Reasons and Health Consequences," Journal of Applied Gerontology 15, 325-344.

Clark, D.E., T.A. Knapp, and N.E. White, 1996. "Personal and Location-Specific Characteristics and Elderly Interstate Migration," Growth and Change 27, 327-351.

Clark, D.E. and W.J. Hunter, 1992. "The Impact of Economic Opportunity, Amenities and Fiscal Factors in Age-Specific Migration Rates," Journal of Regional Science 32(3), 349-365.

Conway, K.S. and A.J. Houtenville, 1998. "Do the Elderly 'Vote with Their Feet'?" Public Choice 97, 663-685.

, 2001. "Elderly Migration and State Fiscal Policy: Evidence from the 1990 Census Migration Flows," National Tax Journal 54(1), 103-124.

, 2003. "Out with the Old, In with the Old: A Closer Look at Younger Versus Older Elderly Migration," Social Science Quarterly 84(2), 309-328.

Cromartie, J.B., 1998. "Net Migration in the Great Plains Increasingly Linked to Natural Amenities and Suburbanization." www.ers.usda.gov/publications/rdp/rdp298/rdp298 e. pdf (August 14, 2004).

, 2004. "Nonmetro Migration Continues Downward Trend." www.ers.usda.gov/ publications/ruralamerica/ra174/ra174k.pdf (September 20).

Deller, S.C., 1995. "Economic Impact of Retirement Migration," Economic Development Quarterly 9(1), 25-38.

Deller, S.C. and V. Lledo, 2007. "Amenities and Rural Appalachian Growth," Agricultural and Resource Economics Review 36(1), 107-132.

Deller, S.C., D.W. Marcouiller, and G.P. Green, 1997. "Recreational Housing and Local Government Finance," Annals of Tourism Research 24(3), 687-705.

Deller, S.C., T.S.H. Tsai, D.W. Marcouiller, and D.B.K. English, 2001. "The Role of Amenities and Quality of Life in Rural Economic Growth," American Journal of Agricultural Economics 83(2), 352-365.

Dissart, J.C., 2003. "The Role of Outdoor Recreation Facilities in Remote Rural Economic Development Planning: An Exploratory Approach." Unpublished Ph.D. Dissertation, Department of Urban and Regional Planning. University of Wisconsin Madison.

Duffy-Deno, K.T., 1998. "The Effect of Federal Wilderness on County Growth in the Intermountain Western United States," Journal of Regional Science 38(1), 109-136. 
Duncombe, W., M. Robbins, and D. Wolf, 2000. "Chasing the Elderly: Can State and Local Governments Attract Recent Retirees?" Paper No. 22. Center for Policy Research, Maxwell School of Citizenship and Public Affairs, Syracuse University: Syracuse, NY.

English, D.B.K., D.W. Marcouiller, and H.K. Cordell, 2000. "Tourism Dependence in Rural America: Estimates and Effects," Society \& Natural Resources 13, 185-202.

Ferguson, M., K. Ali, M.R. Olfert, and M. Partridge, 2007. "Voting with Their Feet: Jobs versus Amenities," Growth and Change 38(1), 77-110.

Fotheringham, S., C. Brunsdon, and M. Charlton, 2002. Geographically Weighted Regression: The Analysis of Spatially Varying Relationships. Wiley: Chichester.

Fotheringham, A.S., M.E. Charlton, and C. Brunsdon, 2001. "Spatial Variations in School Performance: A Local Analysis Using Geographically Weighted Regression," Geographical and Environmental Modelling 5(1), 43-66.

Gale, L.R. and W.C. Heath, 2000. "Elderly Internal Migration in the United States Revisited," Public Finance Review 28(2), 153-170.

Goe, W.R. and G.P. Green, 2005. "Analyzing the Relationship between Amenities and Change in the Well-Being of Nonmetropolitan Localities," in G.P. Green, S.C. Deller, and D.W. Marcouiller (eds.), Amenities and Rural Development: Theory, Methods and Public Policy. Edward Elgar Publishing: Northampton, MA.

Graves, P., 1980. "Migration and Climate," Journal of Regional Science 20(2), 227-237. , 1983. "Migration with a Composite Amenity: The Role of Rents," Journal of Regional Science 23(4), 541-546.

Green, G.P., S.C. Deller, and D.W. Marcouiller (eds.), 2005. Amenities and Rural Development: Theory, Methods and Public Policy. Edward Elgar Publishing: Northampton, MA.

Green, G.P., D.W. Marcouiller, S.C. Deller, D. Erkkila and N.R. Sumathi, 1996. "Local Dependency, Land Use Attitudes, and Economic Development: Comparisons between Seasonal and Permanent Residents," Rural Sociology 61(3), 427-445.

Greenwood, M.J. and G.L. Hunt, 1989. "Jobs versus Amenities in the Analysis of Metropolitan Migration," Journal of Urban Economics 25, 1-16.

Haas, W.H., 1990. "Retirement Migration: Boon or Burden?" Journal of Applied Gerontology 9(4), 387-392.

Haas, W.H. and W. Serow, 1993. "Amenity Retirement Migration Process: A Model and Preliminary Evidence," Gerontologist 33, 212-220.

He, W. and J.P. Schachter, 2003. "Internal Migration of the Older Population: 1995 to 2000." www.census.gov/prod/2003pubs/censr-10.pdf. (February 16, 2005).

Hope, A.C.A., 1968. "A Simplified Monte Carlo Significance Test Procedure," Journal of the Royal Statistical Society Series B 30, 582-598.

Isserman, A.M., 2001. "Competitive Advantages of Rural America in the Next Century," International Regional Science Review 24(1), 38-58.

Johnson, K.M. and G.V. Fuguitt, 2000. "Continuity and Change in Rural Migration Patterns," Rural Sociology 65(1), 27-49.

Kim, K.K., 2002. "Examining the Distributional Effect of Economic Structure within an Extended Endogenous Growth Framework: A Spatial Econometric Perspective for 
Regional Economic Development Planning,"Unpublished Ph.D. Dissertation, Department of Urban and Regional Planning. University of Wisconsin - Madison.

Lewis, D.J., G.L. Hunt, and A.J. Planting, 2002. "Public Conservation Land and Employment Growth in the Northern Forest Regions," Land Economics 78(2), 245259.

Litwak, E. and C. Longino, 1987. "Migration Patterns among the Elderly: A Developmental Perspective," The Gerontologist 27, 266-272.

Lloyd, C. and I. Shuttleworth, 2005. "Analysing Commuting Using Local Regression Techniques: Scale, Sensitivity, and Geographical Patterning," Environment and Planning A. 37(1), 81-103

Long, L., 1989. Migration and Residential Mobility in the United States. Russell Sage: New York.

Long, L. and K. Hansen, 1979. Reasons for Interstate Migration: Jobs, Retirement, Climate and Other Influences. U.S. Census Bureau, Washington, D.C.

Malczewski, J. and A. Poetz, 2005. "Residential Burglaries and Neighborhood Socioeconomic Context in London, Ontario: Global and Local Regression Analysis," The Professional Geographer 57(4), 516-529.

Marcouiller, D.W., G.P. Green, S.C. Deller, N.R. Sumathi, and D.L. Erkkila, 1996. Recreational Homes and Regional Development: A Case Study from the Upper Great Lake States. University of Wisconsin-Extension: Madison, WI. G3651.

Meyer, J.W., 1987. "County Characteristics and Elderly Net Migration Rates: A Three Decade Regional Analysis," Research on Aging 9, 441-452.

Meyer, J.W. and A. Speare, Jr., 1985. "Distinctively Elderly Mobility: Types and Determinants," Economic Geography 61, 79-88.

Nakaya, T., 2001. "Local Spatial Interaction Modelling Based on the Geographically Weighted Regression Approach," GeoJournal 53(4), 347-358

Newbold, K.B., 1996. "Determinants of Elderly Interstate Migration in the United States, 1985-1990," Research on Aging 18(4), 451-476.

$\mathrm{Ng}$, P. and R. Gunderson, 2006. "Summarizing the Effect of a Wide Array of Amenity Measures into Simple Components," Social Indicators Research 79(2), 313-335.

Oehmke, J.F., S. Tsukamoto, and L.A. Post, 2007. "Can Health Care Services Attract Retirees and Contribute to the Economic Sustainability of Rural Areas?" Agricultural and Resource Economics Review 36(1), 95-106.

Plane, D.A. and F. Heins, 2003. "Age Articulation of U.S. Inter-Metropolitan Migration Flows," Annals of Regional Science 37, 107-130.

Partridge, M. and D. Rickman, 2007. "Persistent Pockets of Extreme American Poverty and Job Growth: Is There a Place-Based Policy Role?" Journal of Agricultural and Resource Economics 32(1).

Partridge, M.D., D.S. Rickman, K. Ali, and S. Olfert, 2008. "The Geographic Diversity of U.S. Nonmetropolitan Growth Dynamics: A Geographically Weighted Regression Approach," Land Economics 84(2), 243-268.

Roback, J., 1982. "Wages, Rents, and the Quality of Life," Journal of Political Economy 90, 1257-1279.

Shaffer, Ron E., Steven C. Deller, and David Marcouiller, 2004. Community Economics: Linking Theory and Practice. Oxford: Blackwell Professional Publishing. 
Shields, M., J.I. Stallmann, and S.C. Deller, 2003. "The Economic and Fiscal Impacts of the Elderly on a Small Rural Region," Journal of the Community Development Society 34(1), 85-106

Stallmann, J. and P. Siegel, 1995. "Attracting Retirees as an Economic Development Strategy: Looking into the Future," Economic Development Quarterly 9, 372-382.

Stallmann, J., S.C. Deller, and M. Shields, 1999. "The Economic and Fiscal Impact of Aging Retirees on a Small Rural Region," The Gerontologist 39(5), 599-610.

Stillwell, J. and P. Congdon, 1991. Migration Models: Macro and Micro Approaches. New York, NY. Belhaven Press.

Voss, P.R., R. Gunderson, and R. Manchin, 1988. "Death Taxes and Elderly Interstate Migration," Research on Aging 10(3), 420-50.

Walters, William, 1994. "Place Characteristics in Elderly Migration Research," Bulletin of Bibliography 51, 341-354.

Wiseman, R. and C. Roseman, 1979. "A Typology of Elderly Migration Based on the Decision Making Process," Economic Geography 55, 324-337. 